\title{
Overlooked benefits of consumer credit growth: impact on formal employment
}

Correspondence: gasik@etu.edu.tr Department of Economics, TOBB University of Economics and Technology, Sogutozu Caddesi, Ankara, Turkey

\begin{abstract}
This paper investigates the role of consumer credit growth and expansion of consumer financial services on the reduction of informal employment in a developing country. I argue that financial services growth should lead to a decline in the share of informal employment given that consumers whose borrowing constraints are relaxed are more likely to purchase goods with consumer credit and more likely to demand formal contracts. I test this hypothesis by exploiting the regional variation in consumer credit growth in Turkey. In order to address the endogeneity of financial services, I employ minority population loss between 1893 and 1935 in as an instrument. The identification strategy relies on the fact that minorities were main users of financial instruments as they were the trading class in the former Ottoman Empire. The results provide evidence in favor of a positive causal impact of consumer credit growth on formal employment, especially on low-skilled labor.
\end{abstract}

JEL Classification: D53, E26, F66, G21, G28, J08, J46, J48

Keywords: Informal employment, Consumer credits, Financial services

\section{Introduction}

Informal employment presents an important policy problem in most developing countries as it has implications on social protection and access to safety nets for millions of individuals. Informality limits tax revenues and at the same time combating with informality requires effective inspection mechanisms and vast public resources. Auditing and inspection are usually inefficient and insufficient, failing to keep up with the growth of businesses in many developing countries. On the other hand, during processes of globalization and financial integration, the increase in consumer credits, use of credit cards, and access to other financial services might produce positive externalities on formal employment through the electronization of payment systems. While there is abundant research on the dynamics of informality and on the impact of financial liberalization on growth, this paper, to my knowledge, is the first one to explore the channels through which consumer credits and changing modes of finance can affect formal employment.

This paper contributes to the literature by documenting the overlooked impact of consumer financial services on formality by providing evidence from Turkey. For the purposes of this research, formal employment is defined as paid employment with registration in the social security system. The use of consumer credits and credit cards (and formal financial services in general) has skyrocketed in Turkey in the last decade, and

(c) The Author(s). 2018 Open Access This article is distributed under the terms of the Creative Commons Attribution 4.0 International License (http://creativecommons.org/licenses/by/4.0/), which permits unrestricted use, distribution, and reproduction in any medium, provided you give appropriate credit to the original author(s) and the source, provide a link to the Creative Commons license, and indicate if changes were made. 
this paper explores to what extent the growth in consumer credits had a causal impact on the reduction of informal employment. The ad in Fig. 1 neatly encapsulates the aim of this research, with advertisers encouraging visitors to Turkey to use credit cards when in the country. Informal employment outside agriculture declined by about 5.3 percentage points from 28.8 to 23.5 between 2009 and 2012 in Turkey, and this research shows that consumer credit growth contributed to the decline in informal employment in Turkish economy. Moreover, the impact is strongest in financial services and administrative support and retail, food, and accommodation sectors and the consumer financial services growth improves the formality prospects of the unskilled labour most.

The novelty of this research is that unlike the existing literature, it focuses on the consumer credit channel as opposed to firm credit because in developing countries the expansion of the financial services sector might yield more immediate benefits for consumers than it does for firms. Evidence shows that small- and medium-sized enterprises (SMEs) in many developing countries still prefer their own sources as opposed to bank credit to finance investments and acquire working capital. For instance, the World Bank's Investment Climate Assessment (ICA) for Egypt illustrates that the percentage of firms

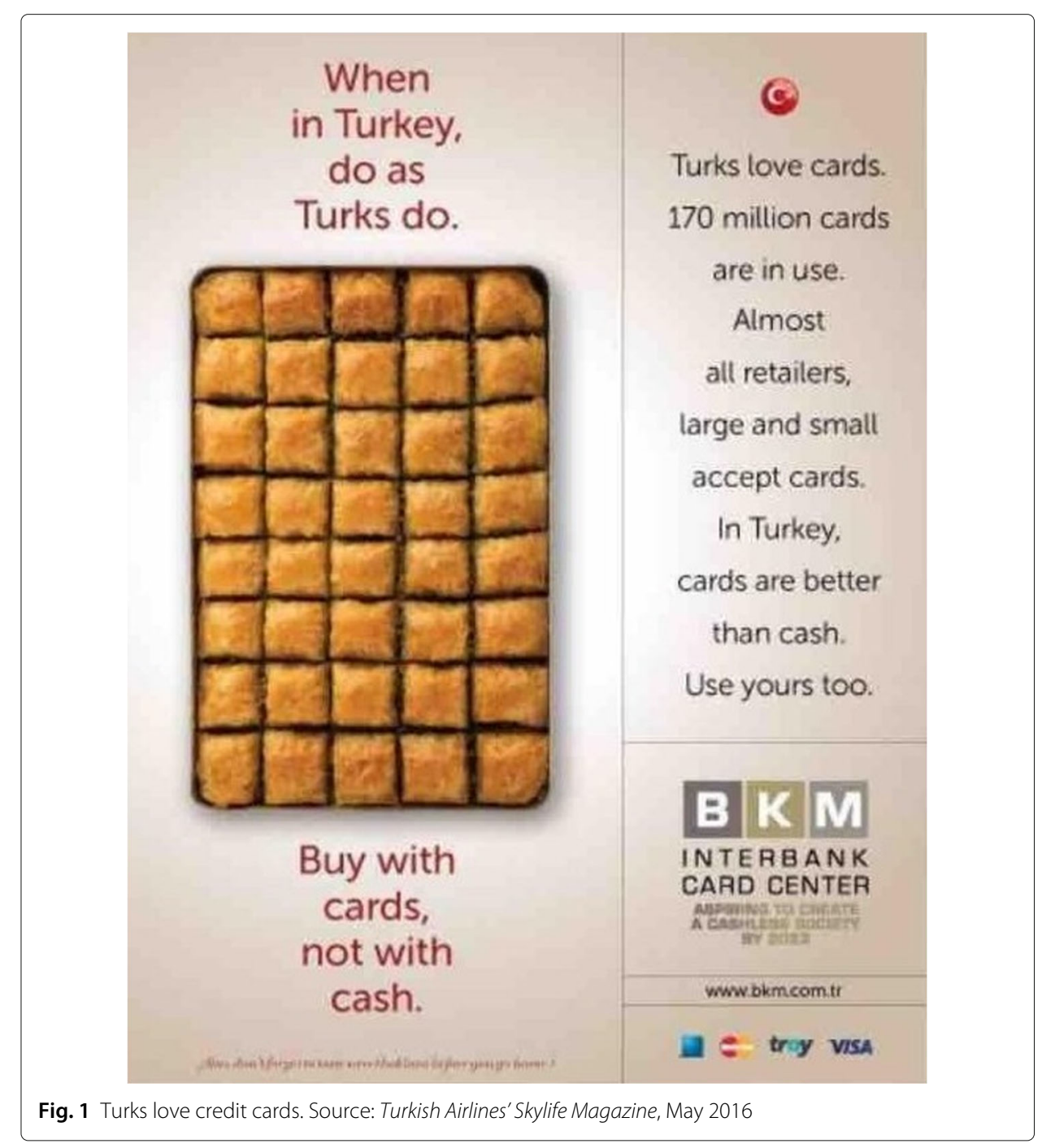


which possess bank loans were $11.4 \%$ in 2008 (which actually fell from $17.4 \%$ in 2004). ${ }^{1}$ The same survey for Turkey shows that only half of the firms that were surveyed in 2009 possessed outstanding loans (World Bank 2007), whereas the average Turkish citizen owns more than one credit card at a time. Low rates of bank borrowing by firms in some middle-income countries might stem from the fact that bank financing is costlier for SMEs, or could stem from cultural differences regarding risk perceptions. Nevertheless, if the expansion of financial services affects formal employment, the impact working through consumer services could be as crucial as the firm credit channel.

In this paper, I test this hypothesis by using Turkish Labour Force Surveys between 2009 and 2012 and regional consumer credit data for Turkey. Due to the endogenous nature of consumer credits and formal employment, I use a unique data set to construct instruments with exogenous variation, that is the loss of Armenian and Greek minorities in the former Ottoman Empire between 1893 and 1935. The identifying assumption is that Armenian and Greek minorities were the main trading classes of the Empire and hence were the main users of the financial services and that their loss dealt a permanent blow to the financial sector. Relying on two-stage results, I find that the expansion of the consumer credits and financial services affects formal employment probability.

The paper is organized as follows. Section 2 starts by briefly explaining the channels through which consumer credit growth and financial services sector expansion might have an impact on formal employment. Section 3 expands why the study focuses on the case of Turkey in search for an empirical link between formality and consumer credit growth. In section 4, I describe the data and present descriptive statistics. I subsequently discuss the identification strategy in section 5. Empirical evidence on the impact of the expansion of consumer credit growth on formal employment are presented in section 6 . Section 7 concludes.

\section{Economic channels of impact}

The impact of the consumer financial services expansion works through three main channels.

- Economic modernization and the penetration of international retail chains: a new consumption environment with economies of scale occasioned by the penetration of international retail chains, the conglomeration of stores in shopping malls, and the increased availability of consumer credits might naturally necessitate the formalization of transactions and employment procedures. Larger enterprises with comparative advantages benefit from rapid urbanization, economic modernization, and the automation of value chains to a disproportionately larger degree, and this transformation alters the mode of spending to the disadvantage of local, mom-and-pop stores, and enterprises. This effect is further amplified by financial liberalization and rapid banking sector growth which facilitates access to consumer credits and credit cards for various income groups in the population, rather than just the wealthy. Therefore, not only is the mode of consumption spending changing, but also the mode of consumption financing in many rapidly growing economies.

- Demand for formal contracts: workers are more likely to demand formal contracts in an environment of inclusive financial services given the requirement of proof of income for access to loans. 
- Effective government inspection: monitoring payments and expenditures under electronic systems is a more effective way of combating informality for the government, given that most jurisdictions aim to improve regulations and infrastructure so as to spread the use of electronic payment technologies.

This undertaking posits that the expansion in the use of financial services among the population has a positive impact on lowering informality as it incorporates the three aforementioned modernizing trends in the economy.

While modernization and changing patterns of consumption might have direct and indirect positive effects on formal employment in every sector, formalization in the wholesale and retail sectors are likely to be highest due to a number of reasons:

- The impact of domestic and international retail chains: Retailers operating in the domestic market that specialize in many different products ranging from clothing to technology or groceries are subject to tighter tax regulations, procedures to acquire permission, and audits. Therefore, it is only natural that jobs created in these sectors are much more likely to be formal than informal as opposed to small, local, traditional, and family-owned stores.

- Visibility channel: In addition to retail chains, many other firms and enterprises operating in the service sector are likely to be exposed to positive and negative externalities in this new form of consumption-food and catering services are two such examples. Retailers as well as restaurants naturally prefer operating where masses of people visit. Increasing visibility helps revenues but also restricts the room for informal modes of doing business such as employing workers informally.

- Outside option channel: Competition among enterprises is likely to increase the need for professionalism and attract employees with better qualifications. Workers with better qualifications, meanwhile, are more likely to request formal contracts and more pleasant working conditions.

An anecdotal evidence comes from a 2013 New York Times article which reports that Chinese graduates typically shun factory shops in favor of urban positions and office jobs in China, even though factory wages are more than two times as high on average. One particular paragraph from the article reads:

"Mr. Wang, 25, has worked only several months at a time in low-paying jobs, once as a shopping mall guard, another time as a restaurant waiter and most recently as an office building security guard. But he will not consider applying for a full-time factory job because Mr. Wang, as a college graduate, thinks that is beneath him. Instead, he searches every day for an office job, which would initially pay as little as a third of factory wages."

It is indeed possible to make a similar line of argument between formal and informal jobs. The study that echoes this research most closely is the work of Catão et al. (2009), which explores the link between firm credit and formalization in Brazil. The study focuses on firms' decisions to move toward formalization, asserting that firms must not only formally register to borrow credit, but also comply with considerable requirements regarding their balance sheets, income flows and tax liabilities. Since the strengthening of communications and data-gathering technologies permits governments to engage in monitoring more effectively and limit illegal borrowing activities, the study investigates the empirical relevance of the credit channel as a driving force of formality. Using the 
financial dependence methodology of Catão et al. (2009), Rajan and Zingales (1998) test whether the economic sectors that are more dependent on domestic bank credit are the site of quicker formal employment expansion as the terms of access to bank credit improve. The study shows that as the aggregate supply of formal bank credit increases, the formalization rate accelerates in the sectors that are more dependent on bank credits.

Research by Chaia et al. (2013) focuses on the empirical foundations of financial inclusion across countries. The premise of the authors' work is built upon a study by Honohan (2008), who documents that approximately 2.5 billion adults worldwide do not use formal or semi-formal financial services, although 2.2 billion do. Although the research sheds light on various areas through which the expansion of financial services might improve the lives of billions, very little attention is directed toward the changing composition of formal-informal employment in relation to banking growth.

A branch in the literature that pursues a related line of inquiry to the focus of this paper investigates the relationship between trade liberalization, financial liberalization, and informality. This branch of literature mostly focuses on the manufacturing sector, ascribing less importance to the implications on the services sector. In line with the hypothesis of this paper, the liberalization literature also suggests that after trade liberalization, multinational firms and chains penetrate domestic markets through foreign direct investments and produce a positive impact on the total share of formal employment in a country, both in the services sector and the manufacturing industry. Scholars, however, have been less successful at examining the mechanisms and interaction between liberalization and informality. In a model developed by Goldberg and Pavcnik (2003), formal employment is subject to labor market regulations and is costly. Trade liberalization results in more competition, while greater competition drives the demand for cheaper informal inputs, meaning the relationship between informal employment and trade liberalization is unambiguously positive. In their model, the degree of reallocation from the formal to the informal sector depends on the degree of flexibility in the labor market. Aleman-Castilla (2006) argues that the least productive firms, most of which are informal, will be forced to exit the market and that trade liberalization will reduce informality. Fugazza and Fiess (2010) employ various macro and micro data sets and argue that the macro data sets support the conventional view that trade liberalization is associated with an increase in informality, while the micro data set does not support this hypothesis.

\section{The case of Turkey}

Turkey constitutes a good example where the regulations encouraged fast consumption growth while at the same time the economy went through a rapid transformation and modernization after emerging from a catastrophic financial crisis in 2001. Thanks to the Stand-by Arrangement Program with the IMF, the economy grew by roughly $43 \%$ since 2000. The growth rates in 2010 and 2011 were the second highest in the world after China at 9.2 and $8.5 \%$, respectively. The rigorous implementation of programs, recapitalization, banking reforms, as well as the decrease in uncertainty thanks to budgetary discipline, resulted in significant capital inflows and foreign direct investments, mostly to the financial intermediation and services sector.

Figure 2 depicts the cumulative FDI flows by sector between 2005 and 2011. According to the statistics provided by the Investment Agency of Turkey, the services sector was the largest recipient of FDI inflows between 2005 and 2011, while financial intermediation 


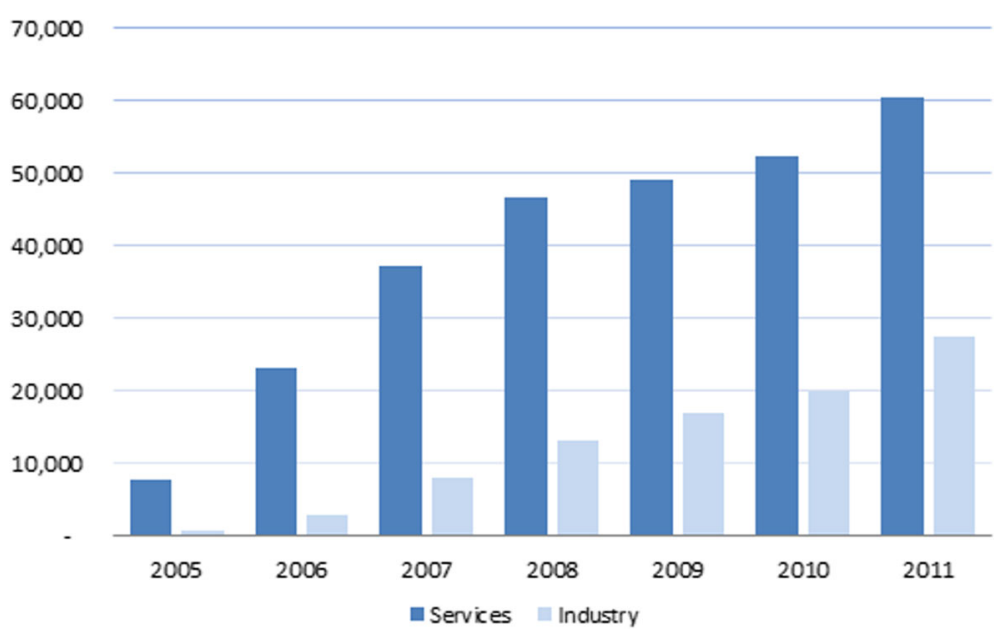

Fig. 2 Cumulative FDI flows by sectors (million US\$)

attracted the largest share within the services sector, ranging from 27 to $83 \%$. During this period, there have been several bank mergers and acquisitions, while international giants such as HSBC and Citibank have also penetrated the Turkish market. ${ }^{3}$

A natural outcome of the expansion of financial intermediation services has been an increase in consumer credits. Historically, the largest recipient of bank credits was SMEs through state-controlled banks during the 1990s. As Fig. 3 shows, the share of consumer credits in total credits went from zero in 2002 to around $25 \%$ by 2012. On the other hand, the share of industrial credits, which constituted $53.7 \%$ of total credits in 2002 , fell to $27.3 \%$ in just 10 years' time.

Figure 4 shows that there has been a strong negative correlation between the informality rate and the consumer credits between 2002 and 2012 at the macro level. Figure 5 shows

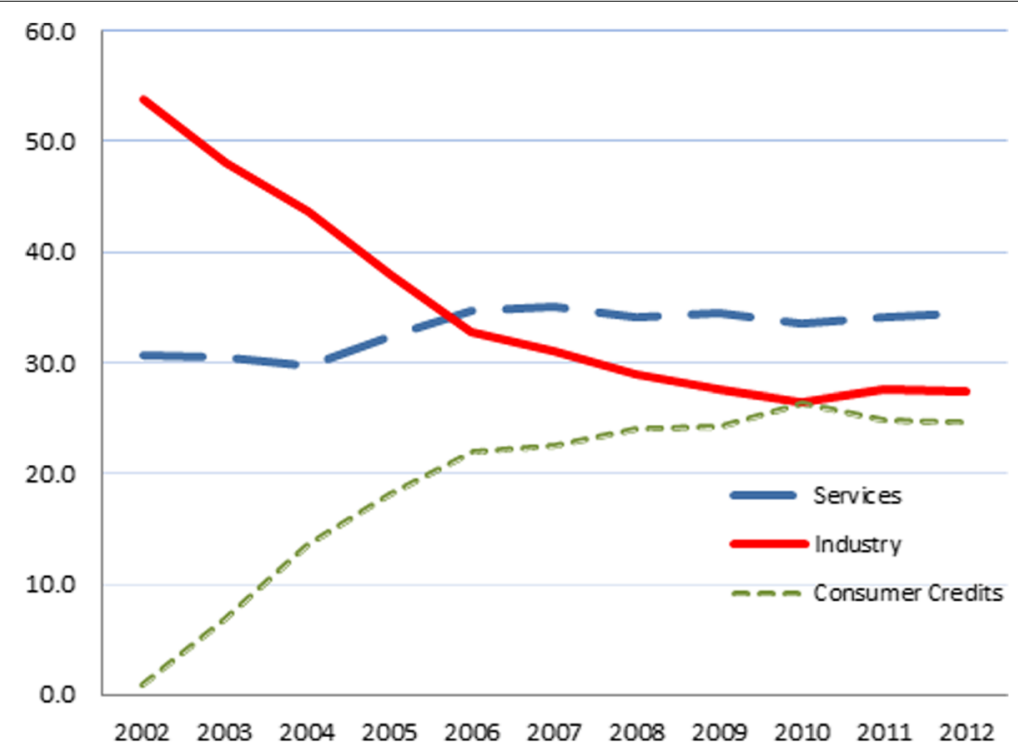

Fig. 3 Share of sectoral banking credits 


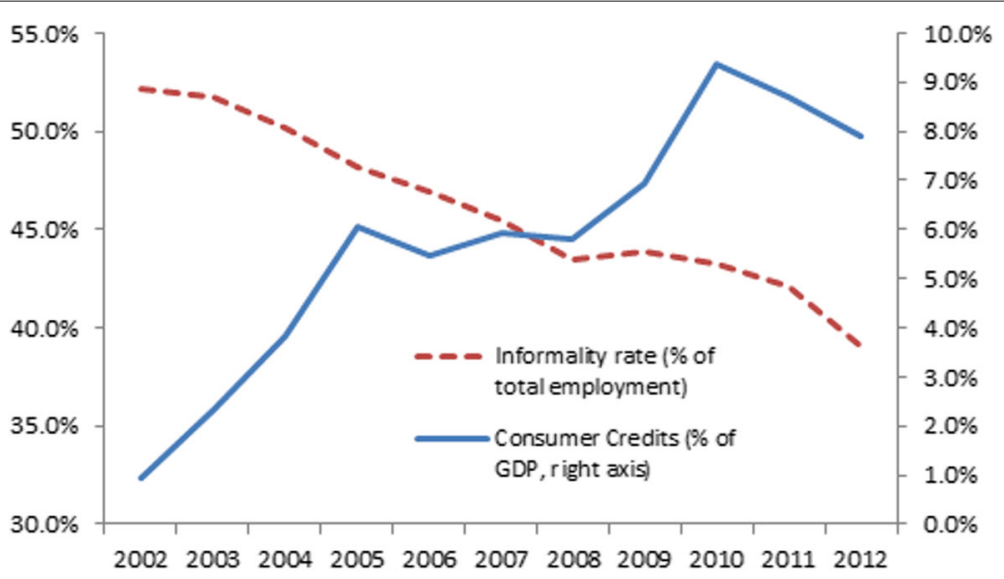

Fig. 4 Consumer credits and informality

that the upward trend in both consumer credits and formality was also taking place across the board in all 26 Nuts2 regions of Turkey.

While Turkey managed to attract short- and long-term inflows that led to cheaper finance during the last decade, another phenomenon that occurred simultaneously with financial services sector growth was the increase in the number of shopping malls, supermarkets, and other retail chains. In essence, two new processes fueled consumption; the first was the economies of scale offered by retail chains that congregated in shopping malls. According to the report by Turkish Federation of Shopping Centers And Retailers (2016), the retail and shopping sector together represented more than 800 thousand employees, 217 billion TL sales volume, an area of 10 million square meters, and 75 thousand shops in Turkey by the end of 2015. Moreover, store-based retailers showed a compound annual rate of growth of $9 \%$ between 2009 and 2014. Total number of shopping centers in Turkey stood at 360 by the end $2015 .{ }^{4}$

The second process that fueled consumption in Turkey was the increasing access to credit cards and the opportunity to pay in several installments for expenditures made via credit cards (a very common practice offered by banks in Turkey). According to a survey published by the Interbank Card Center, 52\% of respondents in 2011 and 61\% in 2012 suggested that their choice of a specific credit card depended on the cards' respective installment options (Interbank Card Center of Turkey 2012). The same survey shows that $39 \%$ of respondents wanted installment options to be offered on consumer durables, while $37 \%$ wanted them for technology goods.

Interbank Card Center data suggests that the number of debit and credit cards had increased from 64 million in 2009 to 91 million by the end 2012-in a country whose population was around 73.6 million at the time-while the number of point-of-service machines increased from 1.4 million to 2.1 million during the same period. The volume of transactions with domestic credit cards rose from 139.1 billion Turkish Liras in 2007 to 355.1 billion TL by the end of 2012. The number of transactions with domestic credit cards was recorded at 1.4 billion in 2007 and at 2.4 billion in $2012 .{ }^{5}$

Moreover, Turkish Banking Association's figures suggest that not only the amount of credit cards and consumer credits increased drastically but also the use of consumer credits became more widespread. The number of individuals who used consumer credits went 


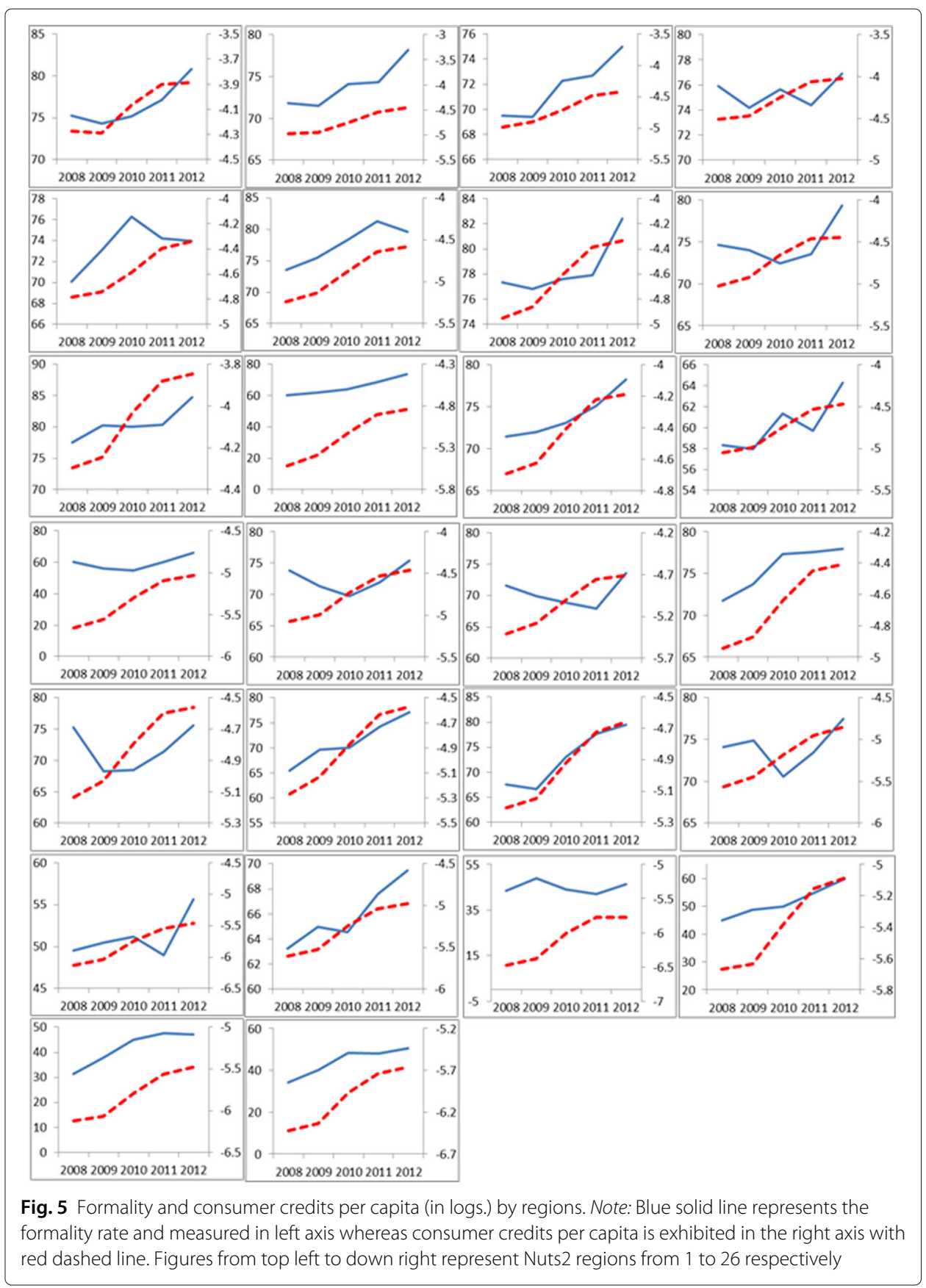

up from 1.2 million in 2002 to over 8.9 million in $2012 .{ }^{6}$ Meanwhile, the rate of informality declined drastically, especially in the services sector in Turkey. Table 1 shows the evolution of the share of formal and informal employment across non-agricultural sectors between 2004 and 2012. Here, I exclude mining and electricity, as well as gas production, from total industrial production as the labor share in those two sub-sectors both represents less than $1 \%$ of the total. The share of formal employment has increased significantly in both the manufacturing and the services sectors. However, when one considers the fact that the service sector employs around $43 \%$ of the entire Turkish labor force-versus just 
Table 1 Employment shares by formality

\begin{tabular}{lllllll}
\hline & Manufact. & Manufact. & Services & Services & Wholesale & Wholesale \\
\cline { 2 - 7 } & 2004 & 2012 & 2004 & 2012 & 2004 & 2012 \\
\hline Formal & 68.7 & 79.3 & 67.8 & 76.2 & 55.6 & 72.1 \\
Informal & 32.3 & 20.7 & 32.2 & 23.8 & 44.4 & 27.9 \\
\hline
\end{tabular}

Source: Own estimates using household labor survey results provided by Turkstat

$18 \%$ in industry, the difference between the two sectors becomes starker in terms of the decline in the actual size of informal employment.

In light of the overwhelming evidence which shows rapid consumer financial services sector growth and decline in informality, this paper aims to explore to what extent there is a causal relationship between the two phenomena. In the next section, I describe data sources before moving on to establishing an empirical link between formal employment and consumer credit growth using Turkish data.

\section{Data description}

The empirical strategy in this paper relies on the regional variation across 26 Nuts2 regions in Turkey between 2009 and 2012. Unfortunately, the aggregate country-level data on consumer credits and financial sector growth does not go sufficiently back in time, leading to too few observations to present meaningful evidence at the macro level. Hence, one is forced to rely on regional data and exploit the differences in credit growth and formality across sub-regions to establish an empirical link.

I combine three main data sets for the purpose of the study. The first data set is regional financial series on the use of consumer credits and outstanding credit card debts. These statistics were collected and disseminated by the Finturk portal of the Banking Regulation and Supervision Agency of Turkey (BRSA) for the years 2009 to 2012. Total consumer credits include credits for vehicle purchases, mortgages, bank credit accounts, outstanding credit card debts, and other consumer credits. Regrettably, the BRSA does not provide regional data before 2008 on the grounds that banks reported most of the financial indicators (such as regional credits) as if they pertained to the Istanbul region due to the fact that credits were approved by the headquarters in Istanbul (Turkey's financial capital), even when the real recipient of the credit actually resided elsewhere. Starting from 2008, reporting procedures were improved to reflect the correct regional financial outlook.

An important reason why I do not extend the data beyond 2012 is the Syrian Refugee Crisis. Turkey is among the top recipients of Syrian refugees fleeing from the humanitarian crisis and the war in Syria. Official data by the Ministry of Interior Affairs suggests that the inflows from Syria to Turkey were almost zero around 2011, increasing to 14,240 refugees by 2012, 224,655 refugees by 2013, and 1.5 million refugees by 2014 . As of May 2018, the number of total Syrians in Turkey are estimated to be around 3.5 million. ${ }^{7}$ Evidence on the labor market effects of Syrian refugees in Turkey are somewhat mixed. Ceritoglu et al. (2017) find that the Syrian refugees replaced low-skilled natives in regions with a heavy Syrian presence, and the ratio of informal employment to population fell by 1.9 and 2.6 percentage points for males and females, respectively. They also show that unemployment has increased, while labor force participation and job finding rates have declined for natives, especially for women. Using the same quasiexperimental design, Tumen (2016) finds that Syrian refugee inflows to the treatment 
region in Turkey reduced the likelihood of having an informal job by 2.26 percentage points for natives in those regions compared to the natives in the control region and formal employment to population ratio increased by approximately 0.46 percentage points. Del Carpio et al. (2015) finds sizable impact on informal jobs; the low educated and women experience net displacement from the labor market with effects of around 6 natives for every 10 refugees. Akgündüz et al. (2015) on the other hand suggest that employment appears to be unaffected by the inflow of Syrian refugees into Turkish regions bordering Syria. By limiting the data up between 2009 and 2012, I aim to isolate any possible effects of Syrian refugees, negative or positive on formal employment probability.

Table 2 lists descriptive statistics about average consumer credits, spending by credit cards and number of branches. While real GDP per capita grew by approximately $20 \%$ from 2009 to 2012, real consumer credits per capita increased by $56.1 \%$ and the real credit card debts increased by $49.3 \%$. While the aggregate growth rates are highly impressive, there is significant variation across the 26 regions of Turkey. As Fig. 6 shows, Istanbul, Ankara, Izmir, and the southwest coastline of Turkey fare much better in terms of consumer credit volumes, while the regions in the southeast lag significantly behind. And indeed, the empirical strategy in this paper relies on exploiting these regional differences in measures of consumer finance.

Employment data comes from household labor surveys conducted by Turkish Statistical Institute (Turkstat) between 2009 and 2012. The surveys are rotating panels, with each household being visited four times over an 18-month period. The number of households visited per month is approximately $14,000 .^{8}$ The survey includes detailed information regarding the background of individuals, their education, marital status, labor force

Table 2 Selected financial services indicators

\begin{tabular}{|c|c|c|c|}
\hline & 2009 & 2012 & Change (\%) \\
\hline Consumer credits per capita (TL) & 1789 & 3516 & 96.5 \\
\hline Credit card debt per capita $(\mathrm{TL})$ & 504 & 947 & 87.9 \\
\hline Total number of branches & 9541 & 10,984 & 15 \\
\hline Population per branch & 8088 & 7448 & -7.9 \\
\hline GDP per capita $(\mathrm{TL})$ & 13,870 & 20,880 & 52.9 \\
\hline Real consumer credits per capita $(\mathrm{TL})^{(*)}$ & 10.9 & 17.0 & 56.1 \\
\hline Real credit card debt per capita $(\mathrm{TL})^{(*)}$ & 3.1 & 4.6 & 49.3 \\
\hline Real GDP per capita $(\mathrm{TL})^{(*)}$ & 84.4 & 100.9 & 19.6 \\
\hline \multicolumn{4}{|l|}{ Notes } \\
\hline Consumer credits per capita (\$) & 1158 & 1951 & 68.5 \\
\hline Credit card debts per capita (\$) & 326 & 526 & 61.1 \\
\hline GDP per capita (\$) & 8980 & 11,588 & 29 \\
\hline
\end{tabular}

*Nominal value deflated by CPI (2004=100). Source: Own Estimates using BRSA-Finturk, Turkish Banking Association, Turkstat and Central Bank data 


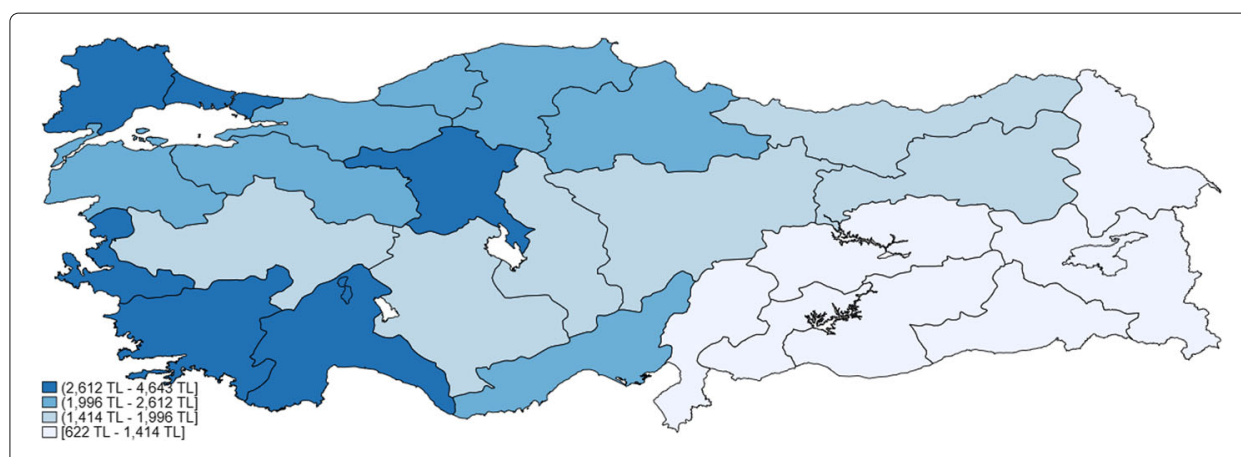

Fig. 6 Consumer credits per capita (in current TL), 2009-2012 average

status, past work experience, sector, region of residence, and presence in, or absence from, the social security system as a registered worker.

There is unfortunately no information as to whether or not the enterprises in which the individuals are employed are formally registered in the tax system. As such, in measuring formal employment, I use the self-reported information on whether or not the individual is registered in the social security system. In all the estimates, however, I exclude agricultural sector employment and unpaid family workers, focusing only on paid employment and self employment since the main focus of this paper is the formalization of employment in non-agricultural sectors catalyzed by the automation of transactions. Table 3 displays the average formality rates for paid employment and self employed outside the agricultural sector. For the period from 2009 to 2012, we see approximately 1.3 percentage point improvement per year in the formality rates for male paid employment whereas the formality growth is slower for female wage earners. On the other hand, formality rates are much lower for self-employed men and women. This provides suggestive evidence on the possibility that the profile of wage earners and self employed are significantly different, a point which we will come back later.

The data for Armenian and Greek population losses by provinces are estimated using 1881/1893 Ottoman Census, provided by Karpat (2003) and 1935 Census of Republic of Turkey. The Ottoman Empire started compiling statistic from 1830s; however, the census collected between 1881 and 1893 is considered to provide the most complete and reliable figures on the population structure of the Empire in the nineteenth century (Karpat (2003)). 1881/1893 Census includes information on the total numbers of Muslims, Armenians, Greeks, Bulgarians, Catholics, Jews, Latinos, and Protestants per

Table 3 Formality rates by type of employment and years

\begin{tabular}{lll}
\hline & Paid employment & Paid employment \\
Men & 2009 & 2012 \\
Women & 75.20 & 80.20 \\
& 76.90 & 79.96 \\
& Self employed & Self employed \\
Men & 2009 & 2012 \\
Women & 46.26 & 53.40 \\
\hline
\end{tabular}

Source: Household labor force surveys, 2009-2012 
Ottoman province. The 1935 Census, on the other hand, does not explicitly provide information on ethnicity, but instead includes breakdown of number of individuals for which the mother tongue is Turkish, Armenian, Greek, or other minority languages listed in the $1881 / 1893$ Census. While there is a possibility that the information on mother tongue might not perfectly measure ethnic background of an individual, measurement error should be small as there is historical consensus on the evidence that the share of Armenian and Greek minorities declined sharply due to conflict, wars, expulsion, and population exchanges. Hence, in calculating the changes in minority population shares from 1893 to 1935, I rely on the information on mother tongue.

An important point to note is that the Ottoman Empire prioritized male populations due to taxation and military service and it is likely that the 1881/1893 Census underestimates the female populations, in fact 1881/1893 Census was the first one to count female populations. In order to minimize the bias, I use only the male population shares for Armenians and Greeks in total male population per region. On the other hand, the Ottoman Empire had an administrative system based on vilayets (provinces) and smaller administrative units called the Sancaks. The newly established Republic of Turkey consisted of 67 provinces and smaller administrative units called the ilce. In estimating the minority population losses, I map vilayets, provinces, and sancaks with the larger Nuts2 administrative borders and aggregate the population figures accordingly. ${ }^{9}$ Table 4 summarizes the population losses by each Nuts2 regions.

In order to establish the empirical link between financial services sector and formal employment, I merge the combined household labor force surveys for 2009-2012 with regional unemployment and GDP data of Turkstat, regional financial indicators of the BRSA, and the population loss data based on censuses. This provides us with a combined data set of 358,580 observations on paid employment and 57,190 observations on self employment.

\section{Identification strategy}

The identification in this paper relies on the historical events that occurred in Anatolia under Ottoman rule at the beginning of the twentieth century. In transition from the empire to the new republic, millions of Muslims and Christian minorities were lost due to wars, conflict, massacres, expulsion (of Armenians), and population exchanges (between Greece and Turkey). 1881/1893 Census shows that the Ottoman Empire had about 1 million Armenian subjects and 1.2 million Greek subjects residing in Anatolia under the current borders of modern Turkey. In the mainland Anatolia, the total population was about 12.4 millions. ${ }^{10} 1935$ Census shows that the number of citizens with Armenian as the mother tongue under the newly established Republic was approximately 57,600 , and the number of citizens with Greek as mother tongue was about 106,000. The census shows that the total population of Turkey was about 16 million by 1935 . While there were also millions of Muslim deaths during the same periods, these were mostly compensated by the migration waves of Muslims coming from Balkans and Caucasus. As will be explained in more detail below, the Armenian and Greek minorities overwhelmingly worked as artisans and were the main trading class who enjoyed higher schooling rates than the Muslim subjects of the empire. The crucial identifying assumption in this section is that the Armenian and Greek minorities were among the main class that utilized financial 


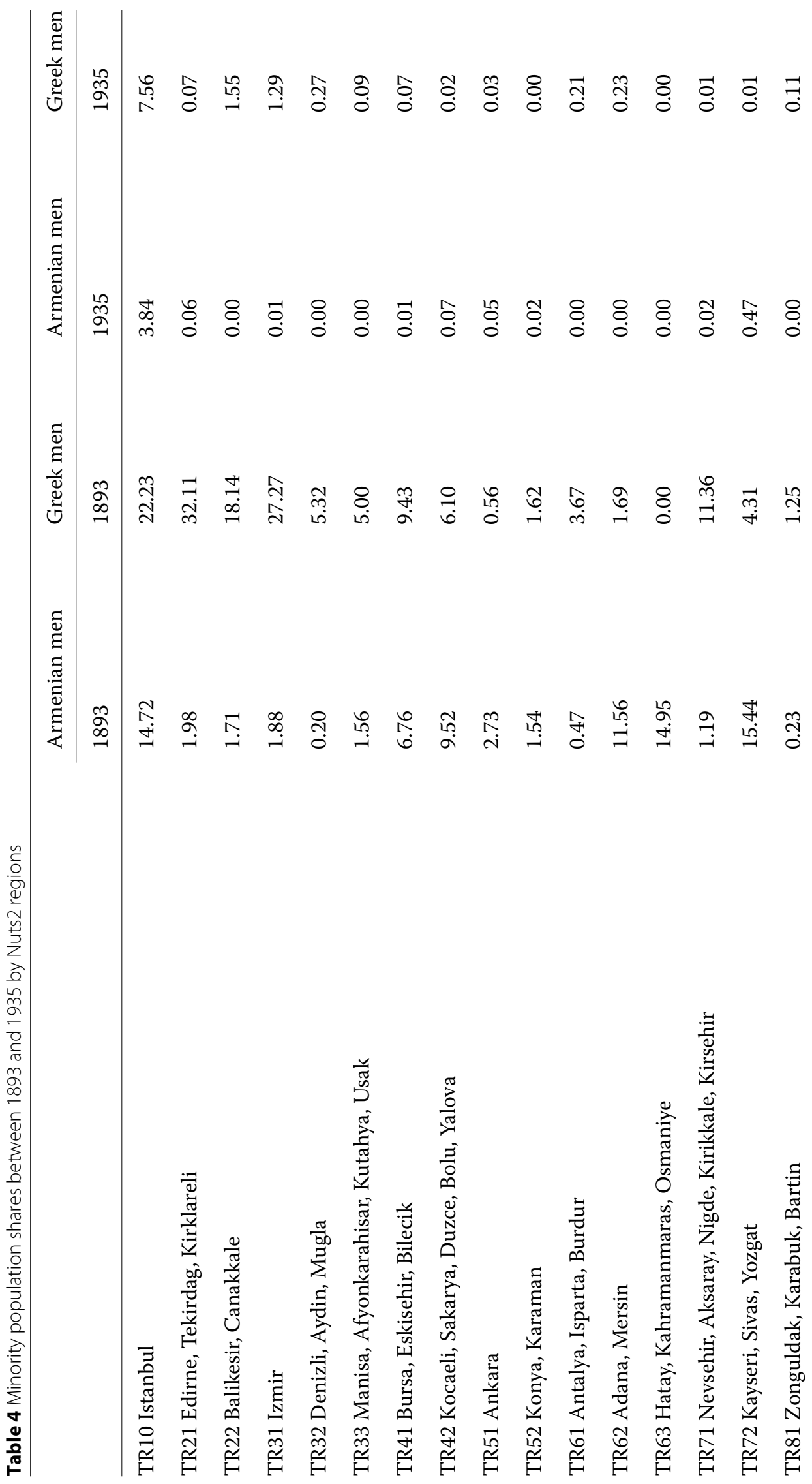




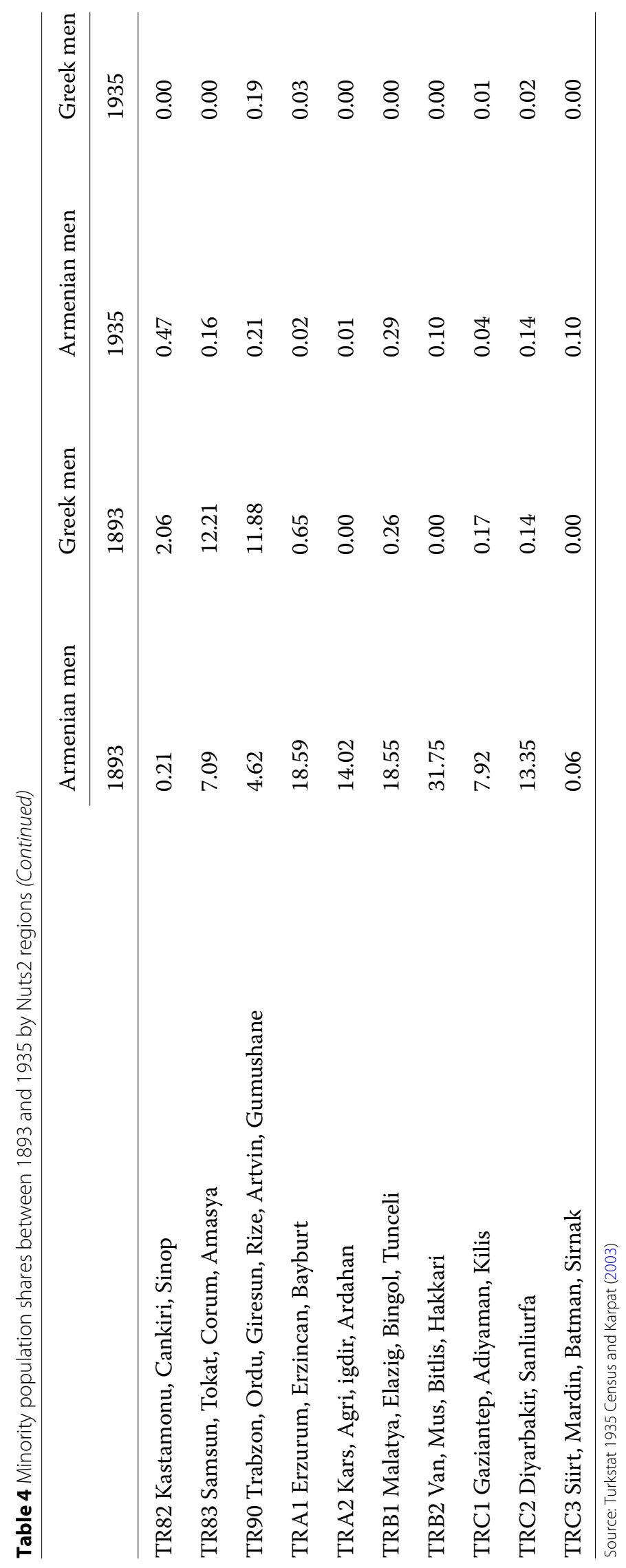


instruments and that their financial know-how was largely lost when these communities vanished, producing long-lasting effects on financial development.

Ungor and Polatel (2011) document that Armenians dominated commerce in the east while Greeks dominated in the west and by early 1915, of the 264 Ottoman industrial establishments, only 42 belonged to Muslims and 172 to non-Muslims. Summarizing the available commercial statistics, the authors state that:

"By the second half of the nineteenth century, as Ottoman Armenians also came to control clothing manufacturing, mining, shipping and milling, they became virtually autarkic nation within the empire's complex social structure...Armenian merchants based in Izmir or Istanbul also branched out to European cities such as London and Manchester and found lucrative businesses there..."

"Erzurum and Diyarbekir, Armenians were famous for their copper works. In Erzurum, the Vemian family of Garin was one of the top armament makers that supplied weapons for the sultans and the imperial court. Some industries were entirely in the hands of Armenians. For example, the characteristic pottery and ceramic works that Kutahya was known for was produced by Armenians since the sixteenth century. So was silk...Silkworm cultivation reached new heights when in 1888 Kevork Torkomian opened a technical school focused on silkworm cultivation in Bursa..."

"In 1884, of the 110 merchants in the north-eastern provincial capital Trabzon, for domestic and international trade a vital port city, 40 were Armenian and 42 were Pontic Greek. According to a 1913 study on Anatolia by the Armenian parliamentarian and writer Krikor Zohrab, of the 166 importers, 141 were Armenians and 13 were Turks. Of the 9800 shop owners and craftsmen, 6800 were Armenians and 2550 were Turks; of the 150 exporters, 127 were Armenians and 23, Turks; of the 153 industrialists, 130 were Armenians and 20 were Turks and finally, of the 37 bankers, 32 were Armenians. In the six eastern provinces, 32Armenian money lenders plied their trade versus only 5 Turkish ones."

Ungor and Polatel (2011) suggest that in Adana by 1915, there were 5 Armenian cotton producers that owed about 13.6 million liras to the German-Levantine Cotton Company whereas the indirect loans to Adana Armenians were around 9.6 million liras. Diyarbakir, another province in South East, was a large and thriving city thanks to its favorable location on the Silk Road and to its copper mines. Ungor and Polatel (2011) suggest that Diyarbakir began raising silkworms locally in the nineteenth century and was producing 300,000 pieces of cloth, part of which was exported. From the onset of the World War I to 1940s, cotton production declined sharply, number of villages producing cotton fell from 324 in 1933 to 79 in 1937. Ungor and Polatel (2011) also suggest that the copper industry had a major blow with minority losses. Before the war, coppersmiths produced around 70 tons of copper on a yearly basis and around 600 masters and workers, all of them Christians earned net profit of 25\%. After deportations in 1915, production dropped to $5 \%$ of its pre-war volume. Today, Diyarbakir is among the poorest cities of Turkey.

Again, as documented by Ungor and Polatel (2011), foreign diplomats raised the alarm on the likely economic disaster of the expulsion. In June 1915, German Vice Consul Kuckhoff reported that "through the extermination of the Armenian element, all trade and commerce in Anatolia will be destroyed and any economic development of the country will be impossible for years to come, for all merchants, industrialists and craftsmen are almost exclusively Armenians." ${ }^{11}$ Joseph Pomiankowski, the Austro-Hungarian military 
attache of the time, reported that the loss of artisans, merchants, traders, and farmers was a major blow to the economy. ${ }^{12}$ As Ungor and Polatel (2011) documented, another German report from Aleppo in 1916 suggested that "since 90\% of trade in the interior is in the hands of Armenians, the result is that the country is facing ruin...With the few exceptions, the evacuated areas there will not be left a single mason, blacksmith, tailor, carpenter, potter, tentmaker, weaver, shoemaker, jeweller, pharmacist, doctor, lawyer or any other professional or trader, the country will actually be in a helpless state." 13

All in all, historical accounts suggest that Armenian and Greek minorities were the trading class of Ottoman Empire and that they were most likely to be the main users of the financial system. Hence, the loss of these communities must have long-term consequences on financial development gaps across Turkey. Indeed, comparing Figs. 6 and 7, we see that the regions which lost higher shares of the two minorities have significantly lower consumer credits per capita today.

An important problem with using the population loss data as an instrument is that this variable is fixed whereas the credit data varies over time. Hence, in order to create exogenous variation, I generate a new variable which adjusts annual total real credits per capita (total credits in Turkey, not credits per region) with minority losses and allocates them accordingly to 26 regions. ${ }^{14}$ More specifically, the instrument that I generate is the following one:

$$
I V_{j, t}=\frac{(\text { TotalConsumerCredits })_{t}}{(\text { TotalPopulationofTurkey })_{t}}\left[1+\Delta \sigma_{j}^{A r m}+\Delta \sigma_{j}^{G r}\right]
$$

where $j$ denotes region and $t$ denotes the time. $\Delta$ operator denotes change from year 1893 to year 1935 and $\sigma_{j}$ is the share of each male minority in total regional male population. By construction, a higher change in the minority share implies bigger losses of minorities in total regional population. This instrument is based on the assumption that had there been no minority losses, regional credits would be higher by now. If the hypothesis that minority losses had long-term negative effects on financial development is true, then we expect the first stage coefficients to be negative, i.e., a region with large minority losses receives less credits that what it should have been receiving had there been no losses.

We now turn to our main equation of interest. In estimating the impact of consumer credits on formal employment, we estimate the following equation by OLS and 2SLS ${ }^{15}$ :

$$
Y_{i, j, t}=\beta_{0}+\beta_{1} X_{j, t}+\beta_{2} Z_{i, j, t}+\beta_{3} D_{t}+\eta_{j}+\epsilon_{i, j, t}
$$

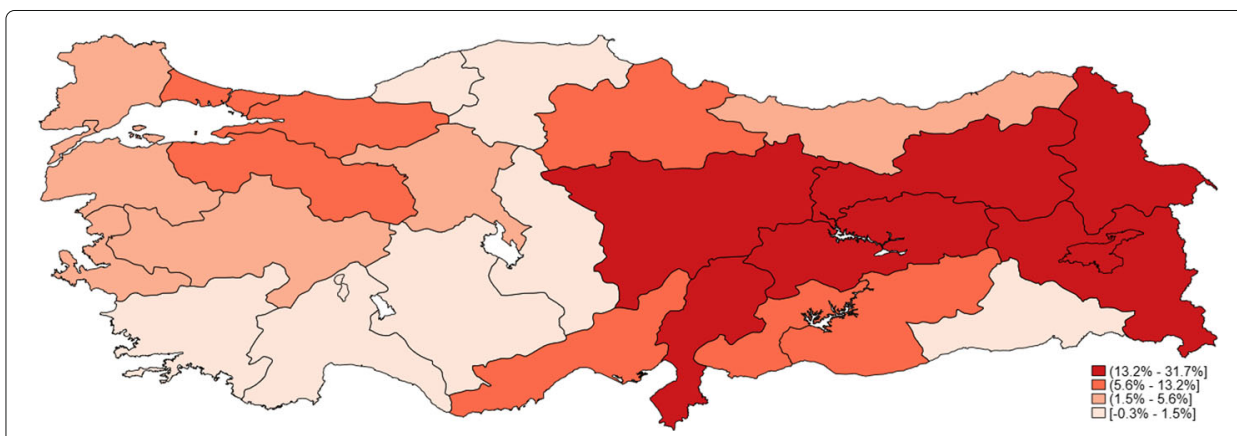

Fig. 7 Total decline in Armenian and Greek population shares between 1893 and 1935 by regions 
where $i$ denotes the individual, $j$ denotes the region, and $t$ denotes the time. $Y_{i, j, t}$ is an indicator which takes on the value equal to 1 if the individual is employed formally, and 0 if the individual is employed without being registered in the social security system. $X_{j, t}$ is the vector of regional variables of interest, namely, (i) real consumer credits per capita (in natural logarithm) or real credit card debts per capita (in natural logarithm) depending on the specification, (ii) GDP per capita (in natural logs), (iii) average real monthly earnings (net of taxes, in natural logarithm), (iv) unemployment rate (\%), (v) net migration rate (\%), (vi) urban population (\%), (vii) average schooling, (viii) and (ix) average firm size (in terms of employment). $Z_{i, j, t}$ is the vector of individual characteristics such as civil status, experience, age, sex, educational status, firm size in terms of employment, permanent or temporary employment, part-time versus full-time employment, sector of employment (Nace Rev.2), occupation (Isco 88), and whether or not the individual lives in an urban area. $D_{t}$ denotes time effects, and $\eta$ denotes region fixed effects. ${ }^{16}$

It is worth mentioning that the government introduced an employment incentive package to subsidize social security contributions by employers in 2008 to limit the impact of the global financial crisis. While the change in legislation targeted female workers of all ages, it only targeted male workers aged between 18 and 29; regionally, however, this resulted in uniform cuts to contributions in all 26 regions without favoring any particular region. ${ }^{17}$ I acknowledge that the availability of regional consumer credit data merely from 2009 on is a weakness, since we possess no data prior to 2009 to control for the full impact of the legislative change. As such, there is a possibility that the analysis mistakenly attributes the impact of legislative change to the increase in financial services. However, there are reasons why this change might not pose a severe problem for the purposes of this paper.

First, reduced social security contribution rates were uniform across Turkey and the estimates include full-time dummies; accordingly, the impact of the legislation should be at least partially controlled for. Second, the legislation targeted mainly female workers due to the fact that the female labor force participation rate in Turkey was as low as $24 \%$ in 2009 where $42 \%$ of female employees worked in the agricultural sector. By the end of 2012, the participation rate had risen to $29 \%$ while $42 \%$ were still employed in the agricultural sector. ${ }^{18}$ As such, the impact of the legislation change is unclear, at least in terms of the structure of female employment. It is very likely that the slow increase in female participation and employment was due to the natural demographic trajectory, with cohorts with higher schooling rates entering the labor force. In terms of male workers, the legislation targeted only those in the 18-29 age group until 2011, but the coverage was later extended to include the older males. Indeed, Balkan et al. (2014) show that on aggregate the subsidy program was ineffective in increasing the employment probabilities of those individuals in both target groups and there was only minor increase in employment probability for women above age 30. On the other hand, Balkan et al. (2016) use men above 30 years old as a control group for women and find that while the employment probabilities did not increase for women, formality rates increased between 2006 and 2011 as compared to the men who were not eligible to participate in the program. In order to address the concern that the effect on formal employment could be coming from the subsidy program rather than consumer credits, I do robustness checks by restricting the sample to men aged 30-64 only in estimating Eq. 2 by OLS and 2SLS. 
Another important factor which can potentially jeopardize the identification in this research is the regional subsidies. Historically, Turkish governments introduced different subsidies at the provincial level to increase investments and achieve convergence across regions. In 2009, the government introduced an incentive package which divided Turkey into four main regions based on the development levels as well as targeting priority sectors. Provinces categorized under region I have the highest socioeconomic development scores while those falling under region IV are the poorest provinces. Table 5 lists the four subsidy regions. 2009 incentive package included reduction in corporate taxes, investment grants, exemption of value added taxes, and customs duty as well as subsidizing social security premium contributions of the employers. More specifically, the government introduced 2 years of social security premium subsidies for high-technology investments in region I and 3 years of social security subsidies for capital intensive investments in region II with the condition that investments are initiated before the end of 2010. As for regions III and IV, social security contributions were subsidized for 5 and 7 years for investments that start before 2010 in agriculture or labor-intensive manufacturing. In 2012, government extended the incentives once again to increase the number of regions from four to six and to introduce further tax exemptions on investments. While to my knowledge there is no quantitative impact analysis on the effects of these subsidies, Eser (2011) shows that between August 2009 and end of 2012, 83\% of the investments

Table 5 Regions of Turkey by development

\begin{tabular}{|c|c|}
\hline Nuts2 regions & $\begin{array}{l}\text { Subsidy regions based on socioeconomic } \\
\text { development }\end{array}$ \\
\hline TR10 Istanbul & I \\
\hline TR21 Edirne, Tekirdag, Kirklareli & । \\
\hline TR31 Izmir & 1 \\
\hline TR41 Bursa, Eskisehir, Bilecik & 1 \\
\hline TR42 Kocaeli, Sakarya, Duzce, Bolu, Yalova & । \\
\hline TR51 Ankara & । \\
\hline TR22 Balikesir, Canakkale & $\|$ \\
\hline TR32 Denizli, Aydin, Mugla & $\|$ \\
\hline TR61 Antalya, Isparta, Burdur & $\|$ \\
\hline TR62 Adana, Mersin & $\|$ \\
\hline TR33 Manisa, Afyonkarahisar, Kutahya, Usak & III \\
\hline TR52 Konya, Karaman & III \\
\hline TR63 Hatay, Kahramanmaras, Osmaniye & III \\
\hline TR71 Nevsehir, Aksaray, Nigde, Kirikkale, Kirsehir & III \\
\hline TR72 Kayseri, Sivas, Yozgat & III \\
\hline TR81 Zonguldak, Karabuk, Bartin & III \\
\hline TR83 Samsun, Tokat, Corum, Amasya & III \\
\hline TRC1 Gaziantep, Adiyaman, Kilis & III \\
\hline TR82 Kastamonu, Cankiri, Sinop & IV \\
\hline TR90 Trabzon, Ordu, Giresun, Rize, Artvin, Gumushane & IV \\
\hline TRA1 Erzurum, Erzincan, Bayburt & IV \\
\hline TRA2 Kars, Agri, Igdir, Ardahan & IV \\
\hline TRB1 Malatya, Elazig, Bingol, Tunceli & IV \\
\hline TRB2 Van, Mus, Bitlis, Hakkari & IV \\
\hline TRC2 Diyarbakir, Sanliurfa & IV \\
\hline TRC3 Siirt, Mardin, Batman, Sirnak & IV \\
\hline
\end{tabular}

Source: Eser (2011) 
subsidized under the program took place in six region I cities, namely Istanbul, Ankara, Izmir, Kocaeli, Tekirdag, and Bursa whereas the region II received the lowest amount of investments with only $14 \%$ of the total subsidized investments. Region II was followed by region IV which received $15 \%$ of total subsidies. In order to minimize the confounding effects of subsidies, I do robustness checks by running separate estimations for each four regions and find that in fact the largest impact of consumer credits was in region II, which received the lowest amount of investments.

\section{Estimation results and discussion}

Table 6 displays the baseline OLS and 2SLS estimations of the effect of consumer credits on formal employment probability of paid employment and self employed. While the OLS estimations are insignificant, 2SLS shows a positive impact of consumer credit growth

Table 6 Consumer credits and formal employment probability

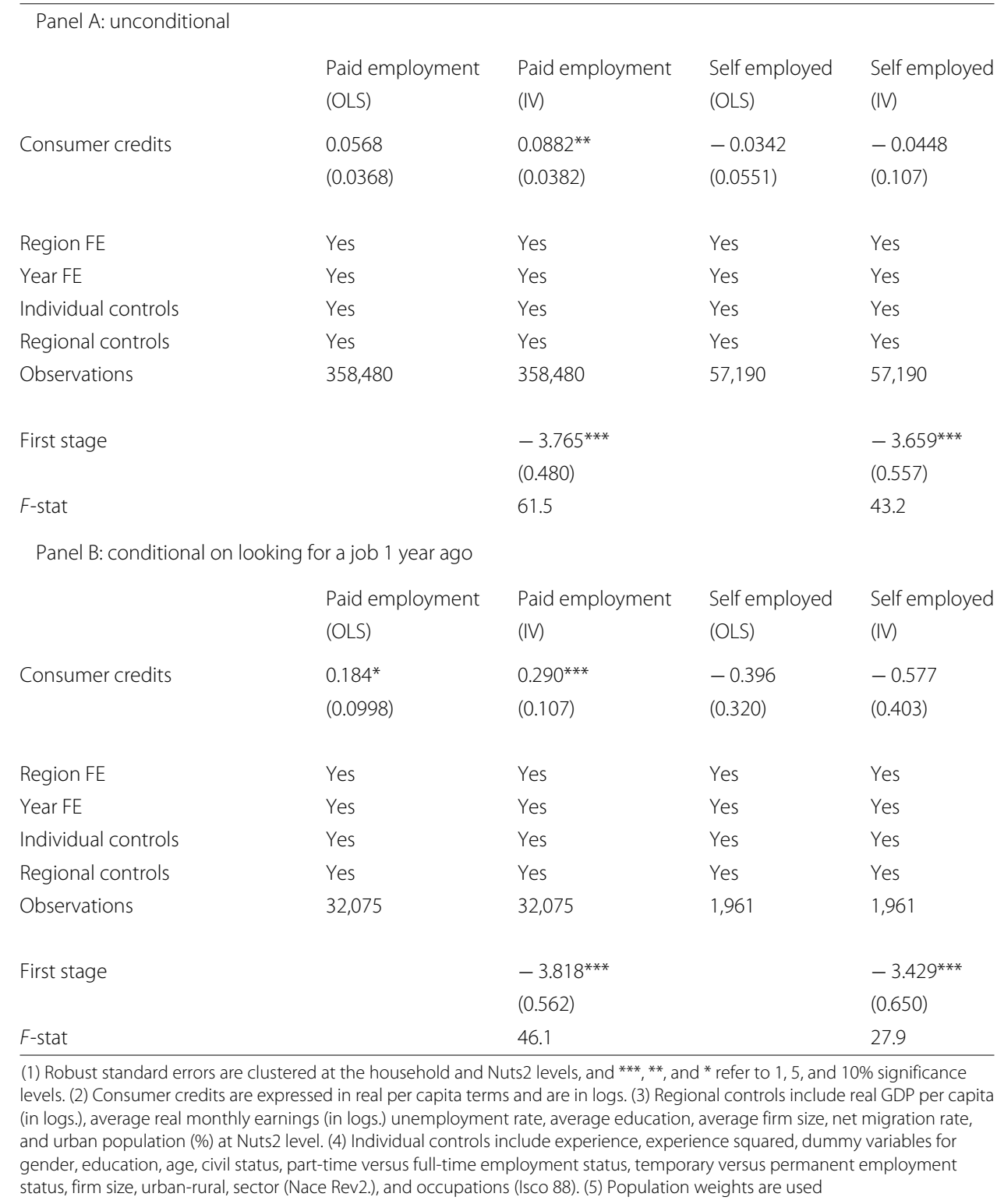


on the formal employment probability of paid employment. More specifically, a $10 \%$ real growth in consumer credits per capita is associated with on average 0.8 percentage point increase in the probability of formal employment of wage earners. The effect is null for self employed under both the OLS and 2SLS. Panel B of Table 6 restricts the data to individuals who report that they were looking for a job 1 year ago. This time the coefficient on paid employment is even more significant and implies a larger impact by the order of around 2.8 percentage point increase in employment probability. The effect is still null for the self employed who reported to have looked for a job in the previous year. The firststage coefficients of the instrument have the expected negative sign in all the four 2SLS estimations with $F$ statistics well above the recommended 10 .

The effect of consumer credit card debts are similar to those of consumer credits but with smaller coefficients. Table 7 displays the baseline OLS and 2SLS estimations. In estimating Eq. 2, Eq. 1 is modified to distribute the nationwide credit card debts per capita by adjusting with lost minority shares. The results show that a 10\% increase in the outstanding credit card debts per capita leads to approximately half a percentage point increase in formal employment probability for wage earners, but there is no effect on self employment. Restricting the sample, panel B of Table 7 shows that an individual on average is about 1.8 percentage points more likely to be formally employed when per capita credits on credit cards grow $10 \%$ in real terms.

It is an important question as to why the impact on wage earners is positive and it is null for self employment. One possible answer is the confounding effects of 2008 employment subsidies. However, looking at average characteristics of self-employed individuals, we see that stark differences with the profile of paid employment. Average schooling is between 5 and 8 years for self employed while it is a little less than high school degree for paid employment. Forty-three percent of the self employed work in the food, accommodation, and retail sector where the same figure is about $20 \%$ for paid employment. A recent survey by Turkstat suggests that $35 \%$ of the self employed and employers reported that they work as self employed or employers because they would like to continue the family business. ${ }^{19}$ About $16 \%$ report that they could not find a paid job. More importantly, the survey shows that $22 \%$ of the subjects felt that the greatest hurdle in the last 12 months was that there were spells of no income, while $20.5 \%$ reported that the most difficult part was that there were no orders during some periods. Thirteen percent reported financing difficulties. Hence, the reason why we see no impact on self employment could be due to the fact that the type of individuals who self-select into self employment are more likely to be financially constrained and hence less likely to benefit from increased financial services.

In order to confirm that the increase in formal employment probability does not come from employment subsidies of 2008, I restrict my sample to men that are aged between 30 and 64 and hence who were not eligible to benefit from incentives in years 2009 and 2011. The coverage was extended to include the men aged above 29 in 2011. In order to capture the change in legislation, I include a dummy for year 2011. Note that I do not drop years 2011 and 2012 to further isolate the subsidies because doing so results in too little variation of consumer credits across regions. Table 8 shows the OLS and 2SLS estimations for wage earner men who are aged between 30 and 64. Year 2011 dummy is statistically insignificant, suggesting that the formal employment probability for men aged between 30 and 64 did not change on average after 2011 while the coefficient on consumer credits is positive and significant. Estimations suggest that a 10\% increase in real consumer credits 
Table 7 Outstanding credit card debts and formal employment probability

\begin{tabular}{|c|c|c|c|c|}
\hline \multicolumn{5}{|c|}{ Panel A: unconditional } \\
\hline & $\begin{array}{l}\text { Paid employment } \\
\text { (OLS) }\end{array}$ & $\begin{array}{l}\text { Paid employment } \\
\text { (IV) }\end{array}$ & $\begin{array}{l}\text { Self employed } \\
(\mathrm{OLS})\end{array}$ & $\begin{array}{l}\text { Self employed } \\
\text { (IV) }\end{array}$ \\
\hline \multirow[t]{2}{*}{ Credit cards } & 0.0343 & $0.0554^{* *}$ & -0.0135 & -0.0286 \\
\hline & $(0.0218)$ & $(0.0246)$ & $(0.0465)$ & $(0.0680)$ \\
\hline Region FE & Yes & Yes & Yes & Yes \\
\hline Year FE & Yes & Yes & Yes & Yes \\
\hline Individual controls & Yes & Yes & Yes & Yes \\
\hline Regional controls & Yes & Yes & Yes & Yes \\
\hline Observations & 358,480 & 358,480 & 57,190 & 57,190 \\
\hline \multirow[t]{2}{*}{ First stage } & & $-6.001^{* * *}$ & & $-5.733^{* * *}$ \\
\hline & & $(0.782)$ & & $(0.884)$ \\
\hline F-stat & & 58.8 & & 42 \\
\hline \multicolumn{5}{|c|}{ Panel B: conditional on looking for a job 1 year ago } \\
\hline & $\begin{array}{l}\text { Paid employment } \\
\text { (OLS) }\end{array}$ & $\begin{array}{l}\text { Paid employment } \\
\text { (IV) }\end{array}$ & $\begin{array}{l}\text { Self employed } \\
(\mathrm{OLS})\end{array}$ & $\begin{array}{l}\text { Self employed } \\
\text { (IV) }\end{array}$ \\
\hline \multirow[t]{2}{*}{ Credit cards } & $0.133^{* *}$ & $0.187^{* * *}$ & -0.302 & -0.369 \\
\hline & $(0.0605)$ & $(0.0660)$ & $(0.198)$ & $(0.267)$ \\
\hline Region FE & Yes & Yes & Yes & Yes \\
\hline Year FE & Yes & Yes & Yes & Yes \\
\hline Individual controls & Yes & Yes & Yes & Yes \\
\hline Regional controls & Yes & Yes & Yes & Yes \\
\hline Observations & 32,075 & 32,075 & 1,961 & 1,961 \\
\hline \multirow[t]{2}{*}{ First stage } & & $-5.930^{* * *}$ & & $-5.357^{* * *}$ \\
\hline & & $(0.887)$ & & $(1.000)$ \\
\hline \multicolumn{2}{|l|}{ F-stat } & 44.7 & & 28.7 \\
\hline \multicolumn{5}{|c|}{$\begin{array}{l}\text { (1) Robust standard errors are clustered at the household and Nuts2 levels, and }{ }^{* * *},{ }^{* *} \text {, and }{ }^{*} \text { refer to } 1,5 \text {, and } 10 \% \text { significance } \\
\text { levels. (2) Credit card debts are expressed in real per capita terms and are in logs. (3) Regional controls include real GDP per capita } \\
\text { (in logs.), average real monthly earnings (in logs.) unemployment rate, average education, average firm size, net migration rate, } \\
\text { and urban population (\%) at Nuts2 level. (4) Individual controls include experience, experience squared, dummy variables for } \\
\text { gender, education, age, civil status, part-time versus full-time employment status, temporary versus permanent employment } \\
\text { status, firm size, urban-rural, sector (Nace Rev2.), and occupations (Isco 88). (5) Population weights are used }\end{array}$} \\
\hline
\end{tabular}

per capita leads to an about 1.2 percentage points increase in the likelihood of formal employment. The probability is significantly higher if the individual was looking for a job in the previous year.

An important empirical question is whether commercial credits extended to firms were also effective in increasing the formality, and if so, how does the impact compare to consumer credits. To answer this question, I rely on the regional commercial data provided by Finturk-BRSA between 2009 and 2012. Commercial credits consist of credits extended to firms in food and tobacco processing, construction, mining, financial institutions, textiles, retail, tourism, agriculture, energy, and maritime industries. This time the first part of our instrument in Eq. 1 is modified to distribute the nationwide commercial credits per capita by adjusting with lost minority shares. Again, we expect to see a negative firststage coefficient, i.e., regions with higher losses are more likely to have lower commercial 
Table 8 Credits and formal employment probability of men aged between 30 and 64

\begin{tabular}{|c|c|c|c|c|}
\hline \multicolumn{5}{|c|}{ Panel A: paid employment, unconditional } \\
\hline & (OLS) & (IV) & (OLS) & (IV) \\
\hline \multirow[t]{2}{*}{ Consumer credits } & 0.0417 & $0.123^{* *}$ & & \\
\hline & $(0.0427)$ & $(0.0554)$ & & \\
\hline \multirow[t]{2}{*}{ Credit cards } & & & 0.0333 & $0.0757^{* *}$ \\
\hline & & & $(0.0272)$ & $(0.0356)$ \\
\hline \multirow[t]{2}{*}{2011 dummy } & 0.0113 & -0.0216 & 0.0111 & -0.00261 \\
\hline & $(0.0246)$ & $(0.0302)$ & $(0.0179)$ & $(0.0214)$ \\
\hline Region FE & Yes & Yes & Yes & Yes \\
\hline Year FE & Yes & Yes & Yes & Yes \\
\hline Individual controls & Yes & Yes & Yes & Yes \\
\hline Regional controls & Yes & Yes & Yes & Yes \\
\hline Observations & 184,432 & 184,432 & 184,432 & 184,432 \\
\hline \multirow[t]{2}{*}{ First stage } & & $-3.766^{* * *}$ & & $-5.984^{* * *}$ \\
\hline & & $(0.493)$ & & $(0.813)$ \\
\hline \multicolumn{2}{|l|}{ F-stat } & 58.3 & & 54.2 \\
\hline \multicolumn{5}{|c|}{ Panel B: paid employment, conditional on looking for a job 1 year ago } \\
\hline & $(\mathrm{OLS})$ & (IV) & $(\mathrm{OLS})$ & $(\mathrm{IV})$ \\
\hline \multirow{2}{*}{ Consumer credits } & $0.299^{* *}$ & $0.522^{* * *}$ & & \\
\hline & $(0.130)$ & $(0.182)$ & & \\
\hline \multirow[t]{2}{*}{ Credit cards } & & & $0.242^{* * *}$ & $0.324^{* * *}$ \\
\hline & & & $(0.0841)$ & $(0.116)$ \\
\hline \multirow[t]{2}{*}{2011 dummy } & -0.0234 & -0.112 & 0.0269 & 0.00154 \\
\hline & $(0.0662)$ & $(0.0851)$ & $(0.0576)$ & $(0.0648)$ \\
\hline Region FE & Yes & Yes & Yes & Yes \\
\hline Year FE & Yes & Yes & Yes & Yes \\
\hline Individual controls & Yes & Yes & Yes & Yes \\
\hline Regional controls & Yes & Yes & Yes & Yes \\
\hline Observations & 13,045 & 13,045 & 13,045 & 13,045 \\
\hline \multirow[t]{2}{*}{ First stage } & & $-3.874^{* * *}$ & & $-6.018^{* * *}$ \\
\hline & & $(0.594)$ & & $(0.913)$ \\
\hline \multicolumn{2}{|l|}{ F-stat } & 42.5 & & 43.5 \\
\hline \multicolumn{5}{|c|}{$\begin{array}{l}\text { (1) Robust standard errors are clustered at the household and Nuts } 2 \text { levels, and }{ }^{* * * * *} \text {, and }{ }^{*} \text { refer to } 1,5 \text {, and } 10 \% \text { significance } \\
\text { levels. (2) Consumer credits and credit card debts are expressed in real per capita terms and are in logs. (3) Regional controls } \\
\text { include real GDP per capita (in logs.), average real monthly earnings (in logs.) unemployment rate, average education, average } \\
\text { firm size, net migration rate, and urban population (\%) at Nuts2 level. (4) Individual controls include experience, experience } \\
\text { squared, dummy variables for gender, education, age, civil status, part-time versus full-time employment status, temporary versus } \\
\text { permanent employment status, firm size, urban-rural, sector (Nace Rev2.), and occupations (Isco 88). (5) Population weights are } \\
\text { used }\end{array}$} \\
\hline
\end{tabular}

credits per capita. The results are provided in Table 9. Once again, we see no effect on self employment; however, 2SLS estimations show positive and significant effect on paid employment. As compared to the coefficient on consumer credits, the magnitude of the commercial credits are lower and a $10 \%$ increase in real per capita commercial credits to firms increase the likelihood of formal employment by about 0.5 percentage points. 
Table 9 Commercial credits and formal employment probability

\begin{tabular}{|c|c|c|c|c|}
\hline \multirow{2}{*}{\multicolumn{5}{|c|}{ Panel A: unconditional }} \\
\hline & & & & \\
\hline & $\begin{array}{l}\text { Paid employment } \\
\text { (OLS) }\end{array}$ & $\begin{array}{l}\text { Paid employment } \\
\text { (IV) }\end{array}$ & $\begin{array}{l}\text { Self employed } \\
(\mathrm{OLS})\end{array}$ & $\begin{array}{l}\text { Self employed } \\
\text { (IV) }\end{array}$ \\
\hline \multirow{2}{*}{ Commercial credits } & -0.00420 & $0.0516^{* *}$ & 0.0180 & -0.0271 \\
\hline & $(0.0107)$ & $(0.0227)$ & $(0.0283)$ & $(0.0670)$ \\
\hline Region FE & Yes & Yes & Yes & Yes \\
\hline Year FE & Yes & Yes & Yes & Yes \\
\hline Individual controls & Yes & Yes & Yes & Yes \\
\hline Regional controls & Yes & Yes & Yes & Yes \\
\hline Observations & 358,480 & 358,480 & 57,190 & 57,190 \\
\hline \multirow[t]{2}{*}{ First stage } & & $-6.433^{* * *}$ & & $-6.047^{* * *}$ \\
\hline & & $(1.136)$ & & $(1.167)$ \\
\hline F-stat & & 32.04 & & 26.87 \\
\hline \multicolumn{5}{|c|}{ Panel B: men aged 30-64 } \\
\hline & $\begin{array}{l}\text { Paid employment } \\
\text { (OLS) }\end{array}$ & $\begin{array}{l}\text { Paid employment } \\
\text { (IV) }\end{array}$ & $\begin{array}{l}\text { Self employed } \\
(\mathrm{OLS})\end{array}$ & $\begin{array}{l}\text { Self employed } \\
\text { (IV) }\end{array}$ \\
\hline \multirow[t]{2}{*}{ Commercial credits } & -0.00377 & $0.0719^{* *}$ & 0.0342 & 0.0294 \\
\hline & (0.0139) & $(0.0347)$ & $(0.0351)$ & $(0.0758)$ \\
\hline \multirow[t]{2}{*}{2011 dummy } & $0.0299 *$ & -0.00739 & $0.0793^{*}$ & $0.0815^{*}$ \\
\hline & $(0.0169)$ & $(0.0289)$ & $(0.0417)$ & $(0.0455)$ \\
\hline Region FE & Yes & Yes & Yes & Yes \\
\hline Year FE & Yes & Yes & Yes & Yes \\
\hline Individual controls & Yes & Yes & Yes & Yes \\
\hline Regional controls & Yes & Yes & Yes & Yes \\
\hline Observations & 184,432 & 184,432 & 39,252 & 39,252 \\
\hline \multirow[t]{2}{*}{ First stage } & & $-6.456^{* * *}$ & & $-5.929^{* * *}$ \\
\hline & & $(1.169)$ & & $(1.186)$ \\
\hline \multicolumn{2}{|l|}{ F-stat } & 30.5 & & 25.1 \\
\hline
\end{tabular}

Hence, the evidence suggests that consumer credits are at least as important as the firm credits to increase formal employment.

In Table 10, I present further robustness checks trying to shut down the effects of regional subsidies. Column (1) displays OLS and 2SLS estimations when Istanbul, the financial capital and the largest region of Turkey, is excluded from the sample. Column (2) displays the results when the poorest 7 regions in the South East of Turkey are excluded from the sample. ${ }^{20}$ Both columns show statistically significant coefficients and the 2SLS estimations suggest a magnitude of around 2.7 and 1.3 percentage points improvement in formal employment probability with a $10 \%$ growth in consumer credits. Looking at each of the four subsidy regions separately in columns from (3) to (6), we see evidence of impact only in the second region which received the lowest share in total investment subsidies by end-2011. On the other hand, it is hard to draw conclusions for regions I, II, and 


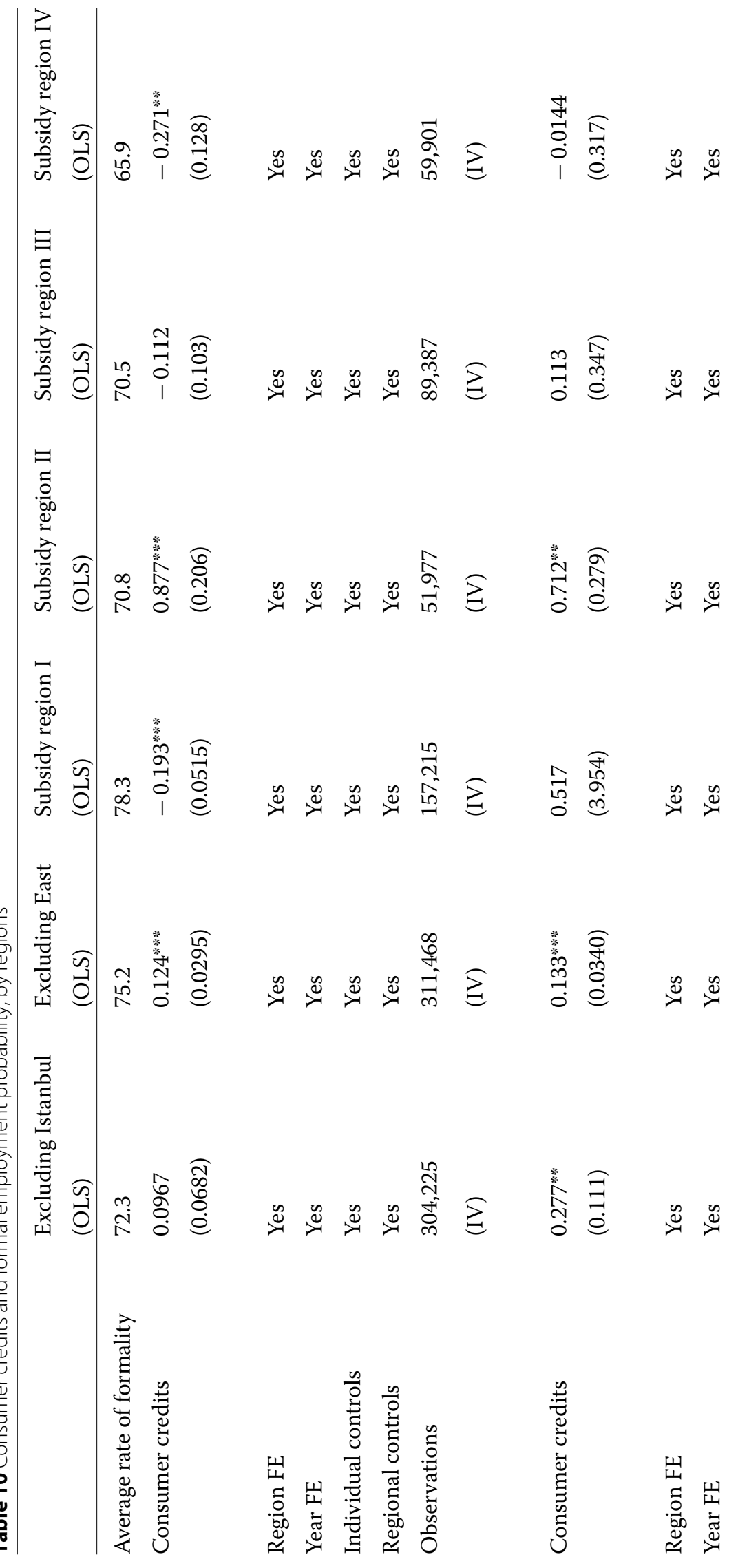




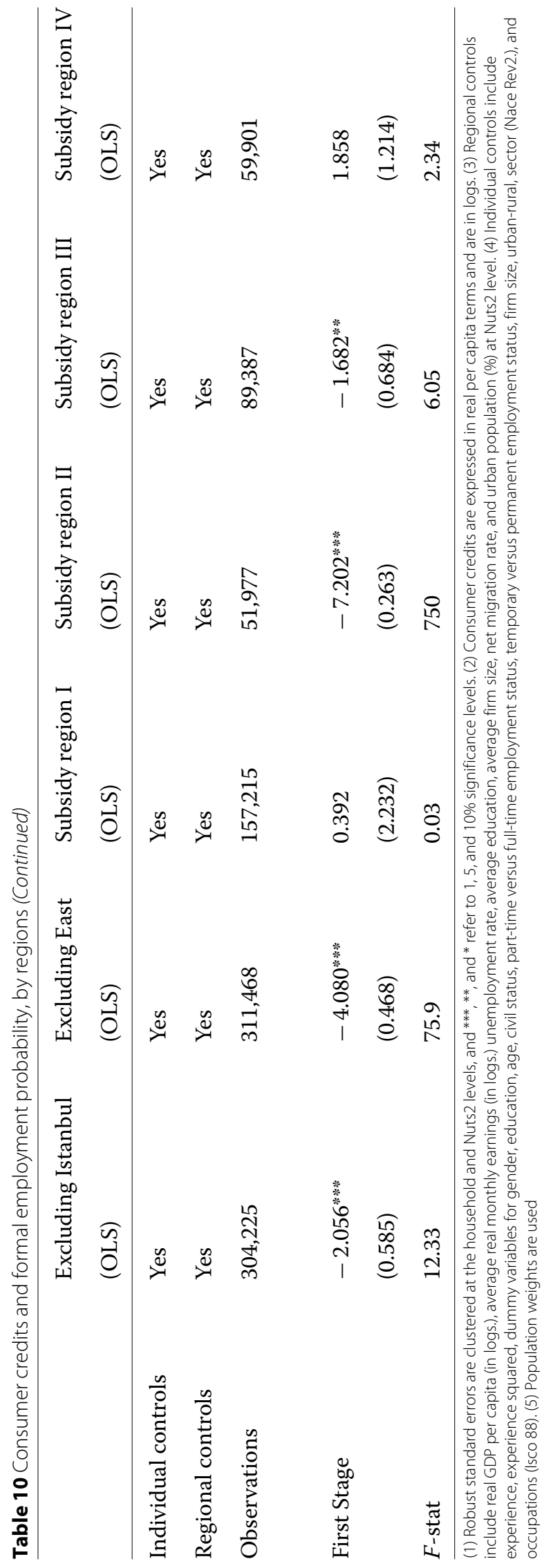


Table 11 Consumer credits and formal employment probability by education

\begin{tabular}{|c|c|c|c|c|c|c|}
\hline \multicolumn{7}{|c|}{ Panel A: paid employment, whole sample } \\
\hline & \multicolumn{2}{|c|}{ Low skilled } & \multicolumn{2}{|c|}{ High school degree } & \multicolumn{2}{|c|}{ College degree } \\
\hline & $(\mathrm{OLS})$ & $(\mathrm{IV})$ & $(\mathrm{OLS})$ & (IV) & $(\mathrm{OLS})$ & (IV) \\
\hline \multirow[t]{2}{*}{ Consumer credits } & 0.0707 & $0.120^{*}$ & $0.0930^{*}$ & $0.169^{* * *}$ & -0.0202 & -0.0430 \\
\hline & $(0.0517)$ & $(0.0687)$ & $(0.0480)$ & $(0.0545)$ & $(0.0226)$ & $(0.0317)$ \\
\hline Region FE & Yes & Yes & Yes & Yes & Yes & Yes \\
\hline Year FE & Yes & Yes & Yes & Yes & Yes & Yes \\
\hline Individual controls & Yes & Yes & Yes & Yes & Yes & Yes \\
\hline Regional controls & Yes & Yes & Yes & Yes & Yes & Yes \\
\hline Observations & 177,534 & 177,534 & 90,969 & 90,969 & 89,977 & 89,977 \\
\hline \multirow[t]{2}{*}{ First stage } & & $-3.780^{* * *}$ & & $-3.686^{* * *}$ & & $-3.824^{* * *}$ \\
\hline & & $(0.505)$ & & $(0.487)$ & & $(0.422)$ \\
\hline \multicolumn{2}{|l|}{ F-stat } & 55.9 & & 57.25 & & 82.25 \\
\hline \multicolumn{7}{|c|}{ Panel B: paid employment, men aged 30-64 } \\
\hline & \multicolumn{2}{|c|}{ Low skilled } & \multicolumn{2}{|c|}{ High school degree } & \multicolumn{2}{|c|}{ College degree } \\
\hline \multirow[t]{2}{*}{ Consumer credits } & 0.0443 & $0.179^{* *}$ & $0.107^{* *}$ & $0.162^{* * *}$ & $-0.0560^{* *}$ & $-0.0908^{*}$ \\
\hline & $(0.0589)$ & $(0.0902)$ & $(0.0519)$ & $(0.0486)$ & $(0.0254)$ & $(0.0490)$ \\
\hline \multirow[t]{2}{*}{2011 dummy } & 0.0402 & -0.0139 & $-0.0334^{*}$ & $-0.0550^{* * *}$ & $0.0301^{* *}$ & $0.0442^{* *}$ \\
\hline & $(0.0377)$ & $(0.0508)$ & $(0.0189)$ & $(0.0195)$ & $(0.0135)$ & $(0.0183)$ \\
\hline Region FE & Yes & Yes & Yes & Yes & Yes & Yes \\
\hline Year FE & Yes & Yes & Yes & Yes & Yes & Yes \\
\hline Individual controls & Yes & Yes & Yes & Yes & Yes & Yes \\
\hline Regional controls & Yes & Yes & Yes & Yes & Yes & Yes \\
\hline Observations & 99,719 & 99,719 & 43,474 & 43,474 & 41,239 & 41,239 \\
\hline \multirow[t]{2}{*}{ First stage } & & $-3.775^{* * *}$ & & $-3.686^{* * *}$ & & $-3.847^{* * *}$ \\
\hline & & $(0.514)$ & & $(0.494)$ & & $(0.442)$ \\
\hline \multicolumn{2}{|l|}{ F-stat } & 53.9 & & 55.7 & & 75.8 \\
\hline
\end{tabular}

IV just based on 2SLS because the first-stage results suggests that the instrument is not strong enough when data for these regions are explored separately.

Does consumer credit growth have differential impact on the skilled and unskilled workers? Skilled workers are on average more likely to be employed under formal contracts and if the consumer credit channel indeed has an impact, one would expect to see the largest effects on unskilled workers or workers with intermediate skills. To test this hypothesis, I divide the data into three skill groups, namely, (i) unskilled: those who have less than or equal to 8 years of schooling ${ }^{21}$, (ii) intermediate skills: those with high school degree or vocational school degree, and (iii) skilled: those with higher education. Table 11 
displays the results. In line with our priors, the estimated coefficients of consumer credits are highest for workers with intermediate and there is no effect on those who have college degrees. A 10\% real per capita increase in consumer credits is associated with about 1.6 percentage points increase in the probability of formal employment for wage earners with intermediate skills on average. If the data is restricted to men aged between 30 and 64, we see that the impact is stronger for low-skilled workers with a magnitude of 1.7 percentage points.

One of the hypotheses of this paper is that the impact on formal employment,-if there is any-should be strongest in the service sectors which rely more heavily on the use of credit cards and consumer credits. In order to explore the sectoral differences, I estimate the probability of formal employment for six sectors, namely, (i) manufacturing, (ii) construction, (iii) retail, food, and accommodation, (iv) transportation and communication, (v) financial services and administrative support, and finally (vi) social and personal services. Sectoral estimates in Tables 12 and 13 show that the effect of real consumer credits are highest in financial services and administrative support sector and the retail, food, and accommodation sector. A $10 \%$ increase in real consumer credits per capita increases the probability of being employed formally about 3 percentage points in the financial services and administrative support whereas the same figure is about 2 percentage points in retail sector. Taking into account the fact that services, especially the sub-sector, retail, food, and accommodation employ the largest share in terms of total employment in Turkey ( $27.1 \%$ on average, followed by $25.1 \%$ in manufacturing), the results are encouraging enough to suggest that there is a natural path for formalization as the consumer financial services sector develops. The relationship also remains significant, albeit weakly for manufacturing and transportation sectors. There is no evidence of impact on construction and social services sectors.

What do these estimates mean? Between 2009 and 2012, the rate of hours worked informally by paid employment in non-agricultural sectors declined by about 5.3 percentage points while consumer credits per capita increased by about $56.1 \%$ in real terms. Assuming the estimates are credible and that the true effects are in the range of 0.8-0.9 percentage points, the figures suggest that in less than 5 years, individuals prospects for formal employment ceteris paribus improved by about 4 percentage points on average with consumer credit growth. This is a remarkable impact on informality with strong policy implications in favor of supporting formal mechanisms of consumer credits, electronization of payment systems, and supporting financial services in developing countries.

\section{Conclusions}

Informal employment is an important labor market problem in most developing countries with implications on social safety, protection, and access to health services for millions of poor households. Informality also limits the collection of public tax revenues and creates a wedge in labor markets. This paper is not concerned with the reasons for informality but with the natural reduction of the share of informality in small, open economies which experience rapid phases of globalization and financial integration. Integration has the benefit of (i) increasing the supply of credits in the domestic economy and (ii) creating economies of scale with more productive firms dominating sales. More specifically, liberalization and integration attract both international firms for domestic production 


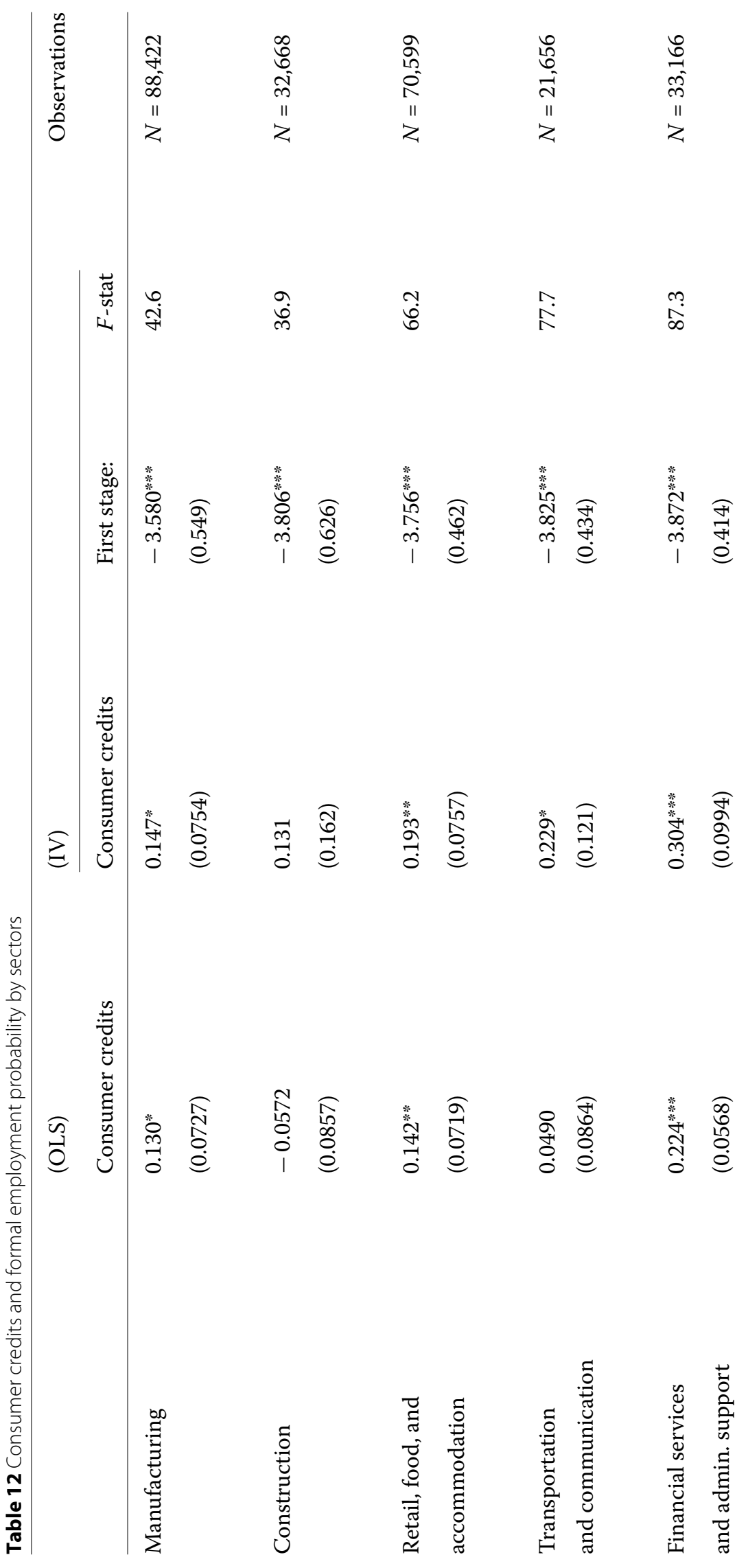




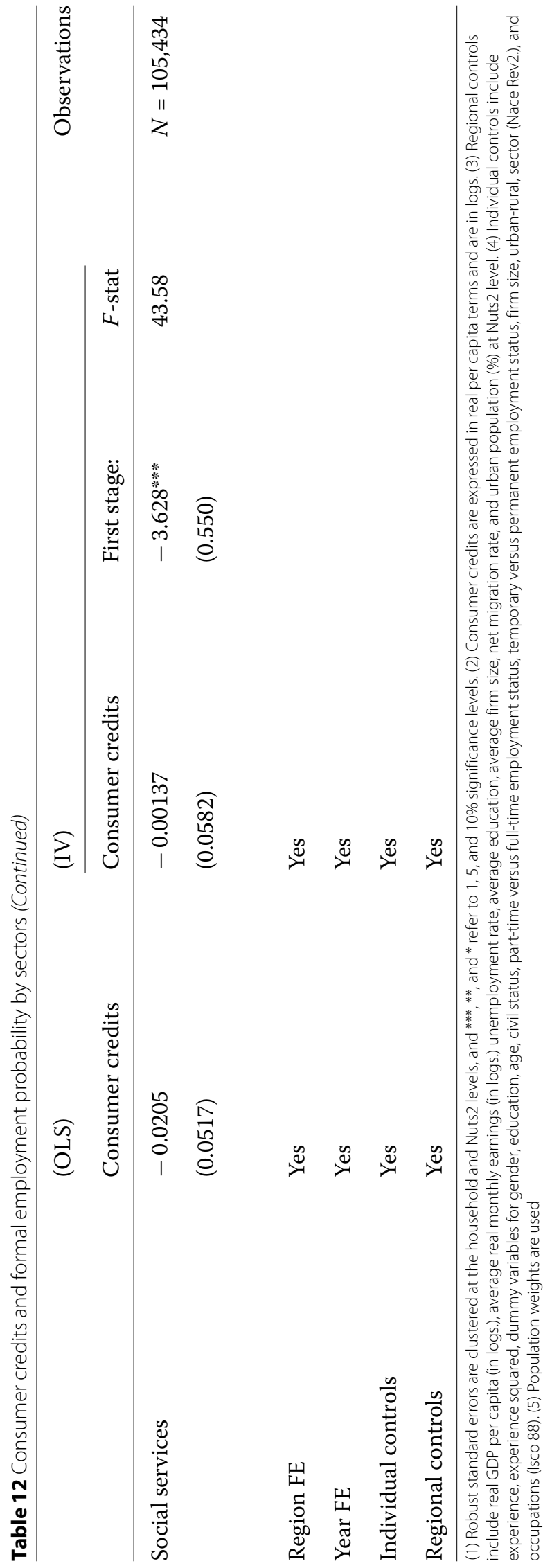




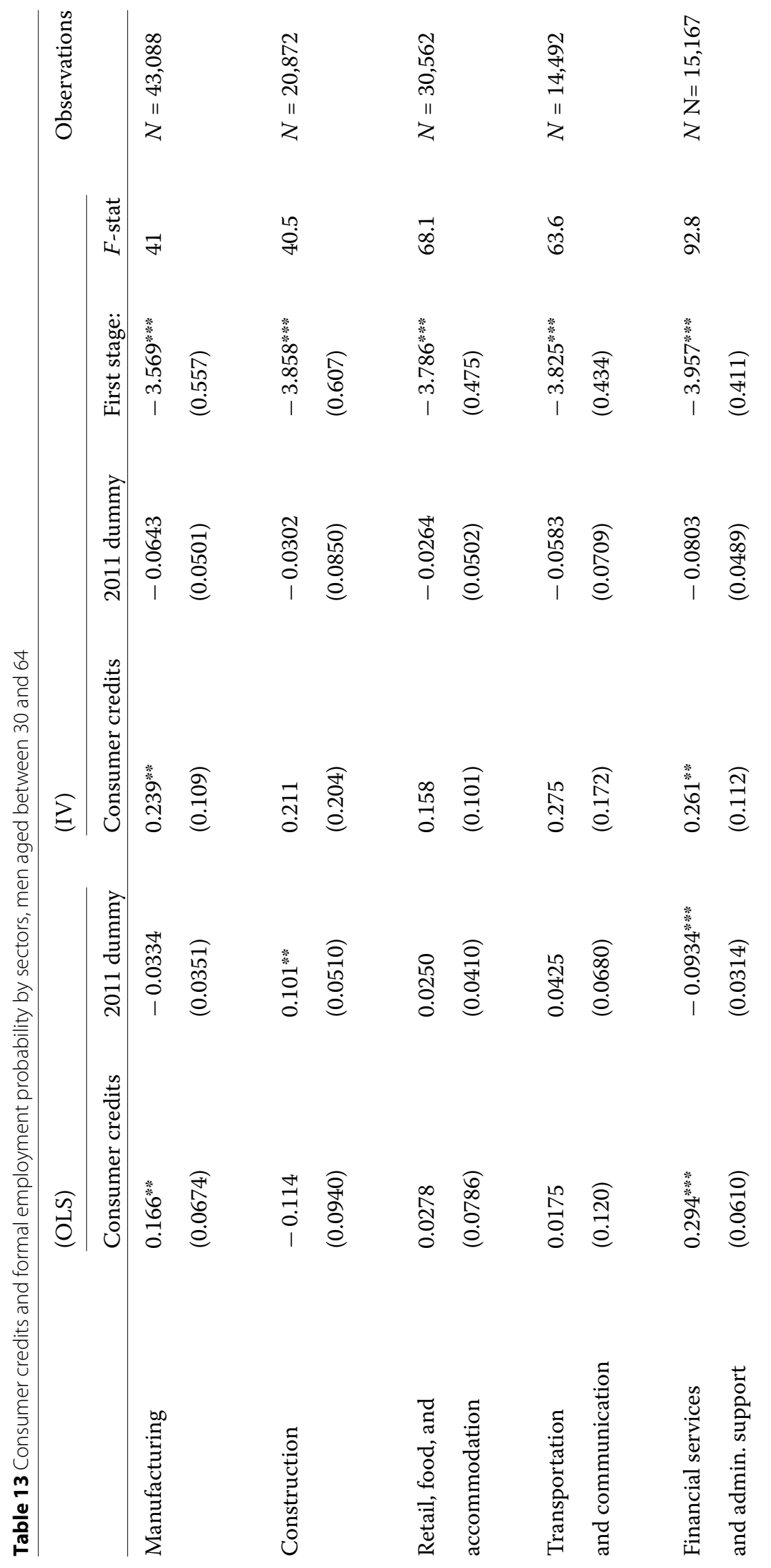




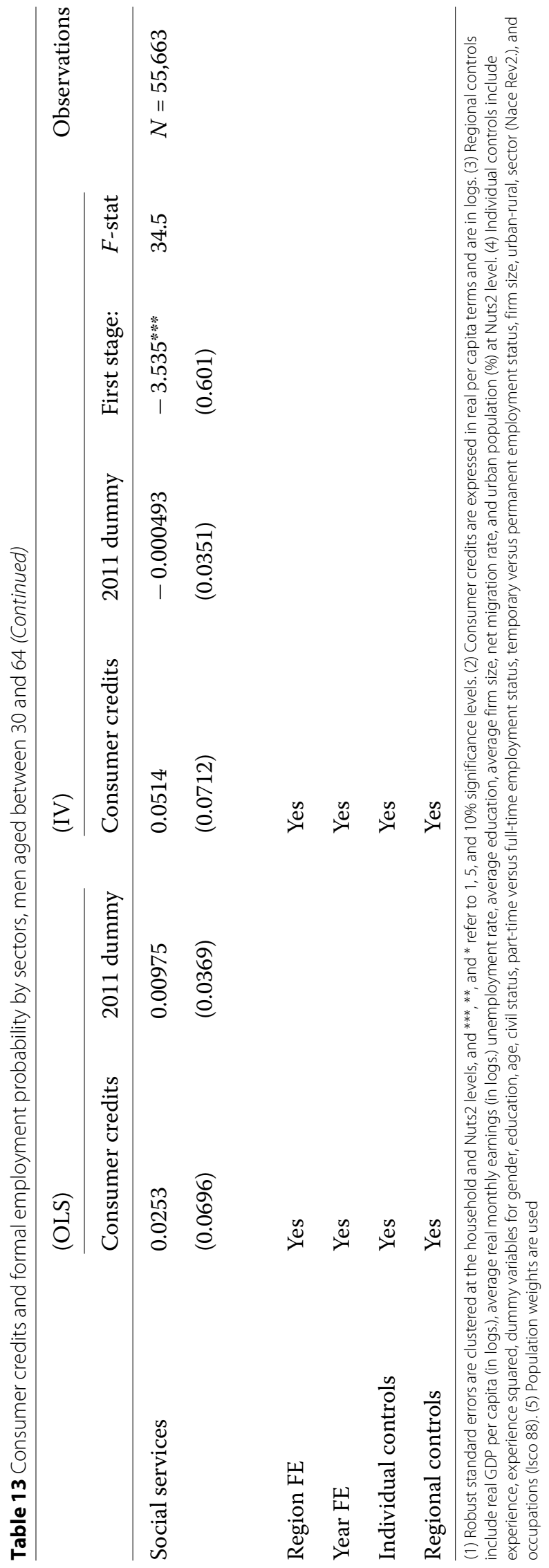


and cheaper credits that are passed onto consumers that had previously face borrowing constraints. As a result of this phase, modes of consumption and payments are typically modernized and old consumption habits die in developing countries.

The novelty of this paper is that it tests the argument that this process should naturally lead to a decline in the share of informality due to the fact that (i) international or bigger firms which have competition advantages are less likely to employ informally and (ii) consumers whose borrowing constraints are now relaxed are more likely to become users of new financial products such as credit cards and consumer credits which were unavailable under autarky. In this new environment, the consumer credit channel might amplify the reduction in informal employment and could be as important as the firm credit channel.

This paper contributes to the literature by providing evidence from Turkey in support of consumer credit channel and expansion of consumer financial services. Over the course of the last decade, Turkey has attracted significant foreign direct investment inflows, especially to service sectors. The share of consumer credits rose from less than 1 to $25 \%$ between 2002 and 2012. Moreover, real credits per capita increased by 56\% between 2009 and 2012. I find that a 10\% real increase in consumer credits improve formal employment probability of paid men by about 0.8 percentage points. While the estimated coefficients are not too large, cumulative effect on formal employment could be large taking into account the fact that Turkey has still the lowest household loans among the OECD countries. Another finding of the paper is that the main beneficiaries of consumer financial services sector expansion is the individuals with intermediate skills and low-skilled labor.

The findings have strong policy implications for developing countries. Considering the limited public resources and pressing needs, countries should prioritize electronization of payment systems, use of financial instruments in combating informality, rather than relying mostly on conventional policy tools such as subsidies and investing vast resources on auditing and inspection.

\section{Data appendix}

- Consumer credits: Provided quarterly by the Banking Regulation and Supervision Agency (BRSA) at a provincial level. Annual figures are then aggregated at the Nuts2 level for 26 regions. Total consumer credits include credits for vehicle purchases, mortgages, bank credit accounts, outstanding credit card debts, and other consumer credits. For the purposes of this study, non-performing consumer credits are excluded. Real consumer credits per capita are estimated as consumer credits deflated by regional CPI and divided by the regional population. Regional CPI are provided by the Turkish Central Bank, while population figures come from the Turkish Statistical Agency (Turkstat).

- Credit card debts: Provided quarterly by the BRSA at a provincial level. Annual figures are then aggregated at the Nuts2 level for 26 regions. Outstanding real credit card debt per capita is estimated as the nominal values are deflated by regional CPI and divided by the regional population.

- Age: Provided as 11 age categories at 5-year intervals. Source: household labour surveys.

- Civil status: Takes on the value 1 if the individual is married and the couple lives together, and 0 otherwise. Source: household labour surveys. 
- Employment location: Takes on the value 1 if the individual lives in urban areas, and 0 otherwise. Source: household labour surveys.

- Education: Years of completed education, provided under six categories, namely, (i) no degree, (ii) primary school, (iii) secondary school, (iv) high school, (v) vocational school, and (vi) higher education. Source: household labour surveys.

- Social security registration: Takes on the value 1 if the individual is registered in the social security administration and 0 otherwise. Source: household labour surveys.

- Experience: Difference between the survey year and the year individual started working. Source: household labour surveys. Industry classification: Categorized under Nace Rev.2. Industries include agriculture, mining, manufacturing, electricity, construction, transportation, trade and finance, and community, social, and personal services. Source: household labour surveys.

- Duration of the job: Takes on the value 1 if the work is permanent and 0 otherwise. Source: household labour surveys.

- Part time versus full time: Takes on the value 1 if the work is full time and 0 if part time. Source: household labour surveys.

- Firm employment size: Measured by the number of people employed in the firm and classified under six categories: (i) less than 10 employees, (ii) 10-24, (iii) 25-49, (iv) 50-249, (v) 250-499, and (vi) 500 and more. Source: household labour surveys.

- Unemployment rate: Provided monthly and on an annual basis by Turkstat at the regional and national level.

- Real wages: Nominal monthly earnings net of taxes deflated by regional CPI index. Source for labor income is household labour surveys, and regional CPI indices are provided by the Turkish Central Bank.

- Urban population (\% of total population): Percent of inhabitants that live in urban areas in a region (population weights are used). Own estimation using the rural-urban information in household labour force surveys.

- Net migration rate: Turkstat defines net migration rate as "the number of net migration per thousand persons who are able to migrate" and calculates as $m_{(. i-i .)}=\left[\left(M_{. i}-M_{i .}\right) /\left(P_{i, t+n}-0.5 *\left(M_{. i}-M_{i .}\right)\right)\right] * k$, where $M_{. i}$ is migration received, $M_{i}$. migration out of the region, $M_{. i}-M_{i}$. net migration, $P_{i, t+n}$ population residing in region $i$ at time $t+n$, and $k$ a constant where $k=1000$.

\section{Endnotes}

${ }^{1}$ See World Bank (2009).

${ }^{2}$ http://www.nytimes.com/2013/01/25/business/as-graduates-rise-in-china-officejobs-fail-to-keep-up.html?pagewanted=all\&_r=0

${ }^{3}$ http://www.invest.gov.tr/en-US/investmentguide/investorsguide/Pages/FDIinTurkey. aspx

${ }^{4}$ TAMPF-PwC Report

${ }^{5} \mathrm{https} / / / \mathrm{bkm} . \mathrm{com} . \mathrm{tr} / \mathrm{en} /$ reports-and-publications/reports-2/

${ }^{6}$ https://www.tbb.org.tr/tr/bankacilik/banka-ve-sektor-bilgileri/istatistiki-raporlar/59

${ }^{7}$ Source: Ministry of Internal Affairs, Directorate General of Migration Management: http://www.goc.gov.tr/icerik3/gecici-koruma_363_378_4713

${ }^{8}$ Unfortunately, the panel dimension of the surveys is not publicly available, necessitating that each survey be treated as a cross-section. 
${ }^{9}$ Mapping of 1893 and 1935 administrative units with Nuts2 regions are available upon request

${ }^{10}$ Note that these figures do not include the Christian subjects in Greece and Balkans

${ }^{11}$ German Foreign Office Archives, R14086, Ab.22101, attachment, report by Vice Consul Kuckhoff, 4 July 1915, in Ungor and Polatel (2011)

12 Pomiankowski, Der Zusammenbruch des Ottomanischen Reiches, 1928 in Ungor and Polatel (2011)

${ }^{13}$ German Foreign Office Archives, R14093, Valentini to Bethmann-Hollweg, 10 September 1916, in Ungor and Polatel (2011).

${ }^{14}$ Note that this instrument is similar to the one in Altindag and Kaushal (2017), in which the authors distribute total annual Syrian refugee inflows by using 1965 Arabic speaking population shares to each province when estimating the impact of refugees in voting behavior in Turkey.

${ }^{15}$ In all estimations, I cluster standard errors by household id and by Nuts 2 regions as this specification yields the most conservative standard errors in comparison to clustering on year, Nuts2, and year-Nuts2

${ }^{16}$ Note that in 2SLS estimations, we deflate the IV by regional CPI and take natural logarithms accordingly.

${ }^{17}$ http://www.tbmm.gov.tr/kanunlar/k5763.html

${ }^{18}$ Data source: Turkstat, http://www.tuik.gov.tr/PreTablo.do?alt_id=1007

${ }^{19}$ http://www.tuik.gov.tr/PreHaberBultenleri.do?id=24917

${ }^{20}$ Regions with Nuts 2 codes starting with TRA1 to TRC3

${ }^{21}$ Those who are illiterate or have 5 years of primary degree or have 8 years of secondary school.

\section{Acknowledgements}

The author would like to thank Barbara Petrongolo, Martin Andrews, Guven Sak, an anonymous referee, the editor, and the participants at European Association of Labour Economists (EALE) Conference at St. Gallen, 2017, for the useful remarks to an earlier version of this paper. The author also thanks Interbank Card Center for sharing data. Responsible editor: Denis Fougère

\section{Competing interests}

The IZA Journal of Labor Policy is committed to the IZA Guiding Principles of Research Integrity. The author declares that she has observed these principles.

\section{Publisher's Note}

Springer Nature remains neutral with regard to jurisdictional claims in published maps and institutional affiliations.

Received: 24 January 2018 Accepted: 29 May 2018

Published online: 12 July 2018

References

Akgündüz Y, Van den Berg M, Hassink W (2015) The impact of refugee crisis on host labor markets: the case of the Syrian refugee crisis in Turkey. IZA discussion papers 8841, Institute for the Study of Labor (IZA). http://ftp.iza.org/dp8841.pdf

Aleman-Castilla B (2006) The effect of trade liberalization on informality and wages: evidence from Mexico. CEP Discussion Papers dp0763, Centre for Economic Performance, LSE. http://cep.lse.ac.uk/pubs/download/dp0763.pdf Altindag O, Kaushal N (2017) Do refugees impact voting behavior in the host country? Evidence from Syrian refugee inflows in Turkey. IZA discussion papers 10849, Institute for the Study of Labor (IZA). http://ftp.iza.org/dp10849.pdf

Balkan B, Baskaya YSS, Tumen S (2014) Evaluating the impact of the post-2008 employment subsidy program in Turkey. 781 IZA Discussion Paper No. 9993, Institute for the Study of Labor (IZA). http://ftp.iza.org/dp9993.pdf

Balkan B, Cilasun S, Turan B (2016) The impact of the Turkish employment subsidy programs on increasing the level of social protection for women. ERF working papers, 1022. Economic Research Forum. http://erf.org.eg/publications/ the-impact-of-theturkish-employment-subsidy-programs-on-increasing-thelevel-of-social-protection-for-women/

Catão L, Rosales M, et al. (2009) Financial dependence, formal credit, and informal jobs: new evidence from Brazilian household data. inter-american development bank working paper series 118. Inter-American Development Bank, Washington 
Ceritoglu E, Yunculer HBG, Torun H, Tumen S (2017) The impact of syrian refugees on natives' labor market outcomes in turkey: evidence from a quasi-experimental design. IZA J Labor Policy 6(1):5

Chaia A, Dalal A, Goland T, Gonzalez MJ, Morduch J, Schiff R (2013) Half of the world is unbanked. In: Cull R MJ, Demirguc-Kunt A (eds). Banking the World, Empirical Foundations of Financial Inclusion. MIT Press, Cambridge. pp 19-42

Del Carpio XV, Wagner M, et al. (2015) The impact of Syrians refugees on the Turkish labor market. World Bank policy research working paper; no. WPS7402. World Bank http://documents.worldbank.org/curated/en/ 505471468194980180/pdf/WPS7402.pdf

Eser E (2011) Turkiye'de Uygulanan Tesvik Sistemleri Ve Mevcut Sistemin Yapisina Dair Oneriler. (Sectoral expertise dissertation). State Planning Organization of Turkey. http://www3.kalkinma.gov.tr/DocObjects/Niew/12365/ Turkiyede_Uygulanan_Yatirim_Tesvik_Sistemleri.pdf

Fugazza M, Fiess NM (2010) Trade liberalization and informality: new stylized facts. UNCTAD blue series papers, 43. United Nations Conference on Trade and Development. http://unctad.org/en/docs/itcdtab44_en.pdf

Goldberg PK, Pavcnik N (2003) The response of the informal sector to trade liberalization. J Dev Econ 72(2):463-496 Honohan P (2008) Cross-country variation in household access to financial services. J Bank Financ 32(11):2493-2500 Interbank Card Center of Turkey (2012) Kart Monitör 2012 Araştırması. [Press Release] https://bkm.com.tr/kurumsaliletisim/basinbultenleri/basin-bultenleri-2012/

Karpat KH (2003) Osmanlı Nüfusu 1830-1914. (Translator Bahar Tırnakçı). Timaş Yayınları, Istanbul ISBN: 978-605-114-141-1 Rajan RG, Zingales L (1998) Financial dependence and growth. Am Econ Rev 88(3):559-586

Tumen S (2016) The economic impact of syrian refugees on host countries: quasi-experimental evidence from Turkey. Am Econ Rev 106(5):456-460

Turkish Federation of Shopping Centers And Retailers (2016) The transforming growth of Turkey's retail industry. Turkish Federation of Shopping Centers And Retailers. http://tampf.org.tr/en/wp-content/uploads/2016/09/thetransforming-growth-of-turkeys-retail-industry.pdf

Ungor U, Polatel M (2011) Confiscation and destruction: the young Turk seizure of Armenian property. London and New York Continuum International Publishing Group

World Bank (2007) Turkey investment climate assessment, volume l: overview of findings and recommendations. World Bank. http://www.tepav.org.tr/upload/files/1253714309r3973.Turkey_Investment_Climate_Assessment_Vol_l.pdf

World Bank (2009) Egypt investment climate assessment, 2009: accelerating private enterprise-led growth policy brief. 809 World Bank. http://schools.aucegypt.edu/research/src/Pages/InvestmentClimateAssessment.aspx

\section{Submit your manuscript to a SpringerOpen ${ }^{\circ}$ journal and benefit from:}

- Convenient online submission

- Rigorous peer review

- Open access: articles freely available online

- High visibility within the field

- Retaining the copyright to your article

Submit your next manuscript at $\boldsymbol{\triangleright}$ springeropen.com 